\title{
A brief warming event in the late Albian: evidence from calcareous nannofossils, macrofossils, and isotope geochemistry of the Gault Clay Formation, Folkestone, southeastern England
}

\author{
Sudeep Kanungo ${ }^{1}$, Paul R. Bown ${ }^{2}$, Jeremy R. Young ${ }^{2}$, and Andrew S. Gale ${ }^{3}$ \\ ${ }^{1}$ University of Utah, Energy \& Geoscience Institute (EGI), \\ 423 Wakara Way, \# 300, Salt Lake City, Utah 84108, USA \\ ${ }^{2}$ Dept. of Earth Sciences, University College London, Gower Street, London WC1E 6BT, UK \\ ${ }^{3}$ School of Earth \& Environmental Sciences, University of Portsmouth, \\ Burnaby Road, Portsmouth PO1 3QL, UK \\ Correspondence: Sudeep Kanungo (skanungo@egi.utah.edu) \\ Published: 30 January 2018
}

\begin{abstract}
This paper documents a warming event across the middle-upper Albian interval in a $\sim 22 \mathrm{~m}$ long section from the Gault Clay Formation of Copt Point, Folkestone (UK). Evidence for the event comes from three independent datasets: calcareous nannofossils, ammonites, and the bulk sediment carbon and oxygen stable isotope record, which collectively indicate a brief period $(\sim 500 \mathrm{kyr})$ of significant surface water warming (in excess of $6^{\circ} \mathrm{C}$ ) at around 107.5 Ma (the base of the Dipoloceras cristatum Ammonite Zone). A surface water productivity increase based on high percentages of the eutrophic nannofossil Zeugrhabdotus noeliae is found to be concomitant with this warming event, suggesting that surface waters were nutrient-rich and the warming was associated with increased precipitation and run-off, delivering more nutrients into the basin.
\end{abstract}

\section{Introduction}

The Albian stage (12.5 Myr duration; Ogg and Hinnov, 2012) is broadly characterized by global warming, rising sea levels, and greenhouse climates. Our understanding of Albian palaeoclimates largely comes from studying short-term perturbations in the global carbon cycle, known as oceanic anoxic events 1b, 1c, and 1d (e.g., Leckie et al., 2002; Galeotti et al., 2003; Giraud et al., 2003; Herrle et al., 2003, 2004; Jenkyns, 2010; Coccioni et al., 2014) using geochemical data (carbon and oxygen isotopes) and often related to biotic turnovers among marine planktonic and benthic organisms from pelagic deep-sea drilling sites and/or the proto-North Atlantic and western Tethys epicontinental basins (e.g., Erbacher et al., 1999; Herrle and Mutterlose, 2003; Watkins et al., 2005; Wagner et al., 2007, 2008; Huber and Leckie, 2011; Friedrich et al., 2012). Studies have also extended to the high Arctic (Herrle et al., 2015) and the eastern Tethys in
China (Li et al., 2016). Short-term disruptions to this warm and equable climate mode have been suggested, including interludes of global cooling ("cold snap") around the AptianAlbian transition (Pirrie et al., 2004; Mutterlose et al., 2009; McAnena et al., 2013) and brief warming events in the late Albian (Erbacher et al., 2011; Friedrich et al., 2012). In a boreal epicontinental setting, Erbacher et al. (2011) inferred the existence of significant short-term changes of temperature $\left(6-7{ }^{\circ} \mathrm{C}\right)$ in the late Albian of northwestern Germany, based on $\delta^{18} \mathrm{O}$ and $\mathrm{Mg} / \mathrm{Ca}$ analysis of glassy foraminifera. A broader compilation of benthic foraminifera data $\left(\delta^{13} \mathrm{C}\right.$ and $\delta^{18} \mathrm{O}$ ) shows an increasing palaeotemperature trend from the middle to late Albian suggested to be related to the formation of warm, saline bottom waters in the southern high latitudes, proto-North Atlantic Ocean, and Pacific Ocean (Friedrich et al., 2012). This work presents a multi-proxy examination of the Gault Clay within the Anglo-Paris Basin. Here we provide and correlate new palaeoenvironmental data based on 
calcareous nannofossils, ammonites, and carbon and oxygen stable isotopes from the middle to late Albian Gault Clay section at Copt Point, Folkestone (southeastern England), which indicate a brief warming event and accompanying productivity change in surface waters.

\section{Geological setting}

During the mid-Cretaceous, southern England was part of the Anglo-Paris Basin and connected to the tropical-subtropical Tethyan Ocean to the south with occasional links to the North Sea through the Bedfordshire Straits (Fig. 1). The marine basin was established through important marine transgressions in the early Aptian (Prodeshayesites obsoletus Ammonite Subzone; $\sim 126 \mathrm{Ma}$ ) that resulted in temporary links with the East Midlands Shelf via the Bedfordshire Straits, and possibly shallow-water connections with the proto-Atlantic Ocean along the line of the present-day English Channel (Tyson and Funnell, 1987). Tectonic activity in the middle early Albian led to the development of a widespread unconformity, but this was followed by a predominantly transgressive phase that was maintained for the remainder of the Albian (Casey, 1961). At this time, a large northwestern European middle and late Albian epicontinental sea extended from southeastern England across to the North Sea, Denmark, northern Germany, Poland, and into Russia (Tyson and Funnell, 1987). Set within this epicontinental sea, the Gault Clay was deposited at a shallow water depth of 40-60 m (Knight, 1999; Young et al., 2010). The formation is well known for preserving a high diversity of fossils across all biotic groups: molluscs (ammonites, bivalves, gastropods; preserved as original aragonite and calcite); bony fish remains, shark teeth, and vertebrae; crab and lobster carapaces; and for its extensive microfauna and microflora (foraminifera, nannofossils, palynomorphs, ostracods, fish otoliths, etc.). Other commonly found fossils include belemnites, corals, and serpulid worms (Young et al., 2010).

\section{Material and methods}

The sample material was collected from the Copt Point coastal outcrop, $1 \mathrm{~km}$ east of the Folkestone harbour in Kent (see location map and photo, Fig. 2), which is considered as the Gault Clay reference section (Gale and Owen, 2010). In this section, the Gault Clay rests on the Lower Greensand Group, as observed in other exposures along the coast of southeastern England (Owen, 1971, 1975). The total thickness of the Copt Point outcrop is around $25 \mathrm{~m}$, of which, we sampled $\sim 22 \mathrm{~m}$ of the Gault Clay from Bed I to Bed XI for this study (Fig. 3). The age of the Gault Clay is reported as middle to late Albian (Owen, 1971, 1975; Erba et al., 1992; Gale and Owen, 2010). The succession comprises dark to medium grey, fossiliferous, and silty clays interspersed

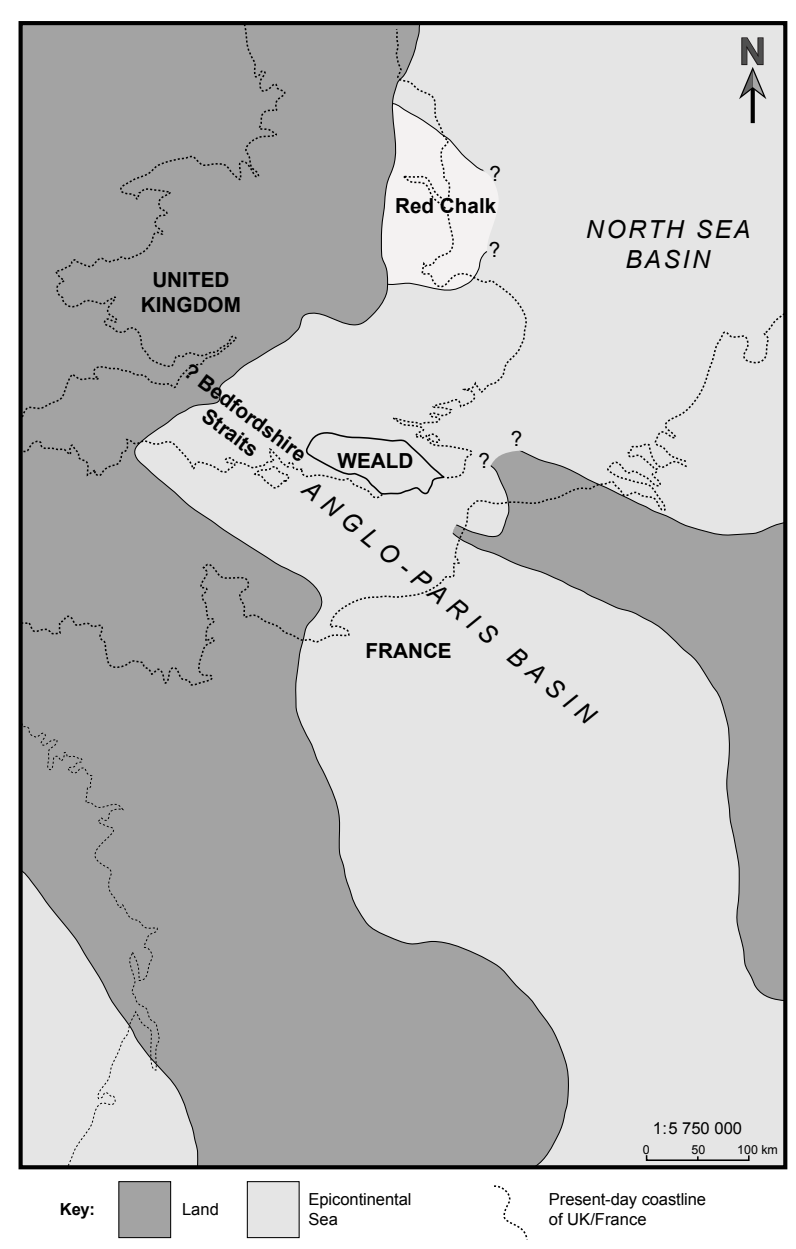

Figure 1. Palaeogeographic setting of the Gault Clay in the Weald of the Anglo-Paris Basin, modified after Owen (1975).

with numerous phosphatic concretions, which are scattered throughout the clay and concentrated on erosional surfaces as thin lags of reworked debris. The clays are often glauconitic, particularly in the lower part of the section (Lower Gault, Beds I-VII) and become lighter in colour with greater carbonate content in the upper part of the section (Upper Gault, Beds VIII-XIII; Fig. 3) (Gale and Owen, 2010). The middle-upper Albian boundary is thought to coincide with a minor hiatus $(<10-20 \mathrm{kyr})$ in the Anglo-Paris Basin, based on missing ammonite zones and subzones. In Folkestone, this hiatus is marked by phosphatic intraclasts, in which the Dipoloceras cristatum Ammonite Subzone clays (Bed VIII) rest disconformably on dark clays of the Anahoplites daviesi Ammonite Subzone (Bed VII) (Owen, 1971; Gale and Owen, 2010).

A total of 41 samples were collected and analysed for nannofossil study, with the lowest sample collected from Bed I $(1.6 \mathrm{~m})$ and the highest (top) sample from Bed XI (21.4 m). The sample spacing varied with an average spacing of $0.5 \mathrm{~m}$ between any two samples (Fig. 3). The sampling strategy 


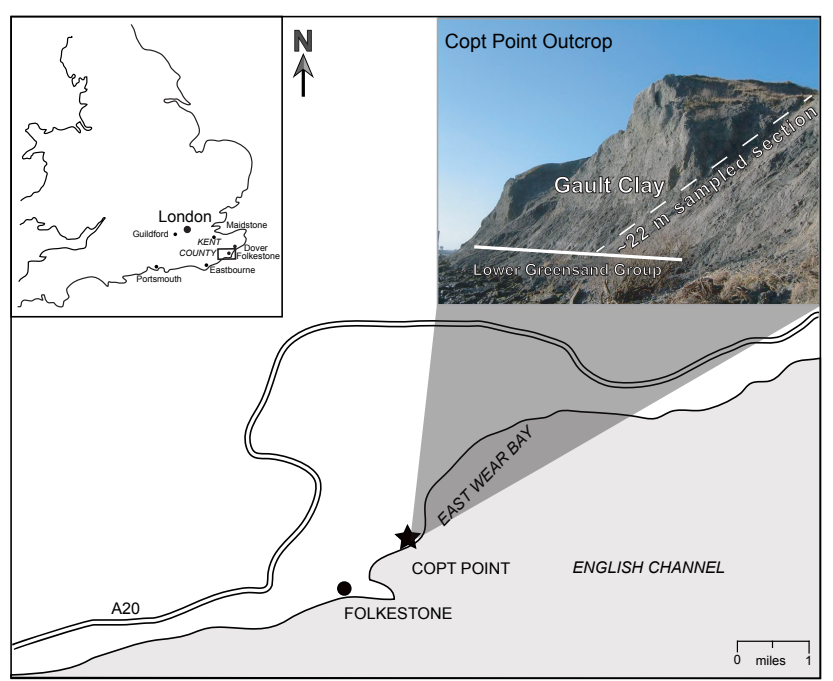

Figure 2. Location and photo of the Copt Point section, Folkestone, SE England.

aimed for additional resolution around the middle-upper Albian boundary (Beds VII-VIII) and to have the best possible correspondence with the isotope samples (44 samples), which were collected during a separate field study. Simple smear slides were prepared using the technique described in Bown and Young (1998). The volume of sediment used was standardized to ensure roughly equal sample density while preparing the smear slides. Nannofossils were viewed using a BH-2 Olympus transmitted light microscope in crosspolarized and phase-contrast light. On each slide $>300$ nannofossil specimens were counted (300-400) in randomly chosen fields of view. All slides were logged for $2-3 \mathrm{~h}$ scanning five to six traverses in order to identify rare and/or biostratigraphically important taxa. An average state of preservation, often ranging between two categories, was assigned to each sample by the author, according to the following criteria. VG (very good) means no etching or overgrowth; most specimens are pristinely preserved and very easily identified. $\mathrm{G}$ (good) means specimens are slightly etched or overgrown, but identification is not impaired. M (moderate) means specimens exhibit moderate effects of secondary alteration from etching and/or overgrowth, but identification of species is still not impaired.

Biostratigraphy was achieved based on first and last occurrences (FO \& LO) of nannofossil marker species logged in the section, using the zonation scheme of Bown et al. (1998). The slides are archived in the Department of Earth Sciences at University College London (UCL). The stratigraphic range chart based on semi-quantitative abundance estimates of nannofossil species (Table S1 in the Supplement) and their relative abundance (\%) data (Table S2) are provided. Relative abundance of a species was calculated using the formula (no. of specimens of a species/total no. of nannofossils counted in a sample) $\times 100$.
Ammonites were collected from Beds I to X by systematically breaking the clay to identify the percentage of brancoceratid species belonging to four genera, i.e., Mojsisovicsia, Dipoloceras, Hysteroceras, and Mortoniceras (Fig. 3, Table S3).

The bulk sediment isotopes $\left(\delta^{18} \mathrm{O}_{\text {bulk }} \%\right.$; $\delta^{13} \mathrm{C}_{\text {bulk }} \%$ o), carbonate $\left(\mathrm{CaCO}_{3}\right.$, wt $\left.\%\right)$, and TOC (total organic carbon, wt \%) was measured for 44 bulk sediment samples (Beds I-XI, 0.1$21.4 \mathrm{~m}$ ) on a PRISM mass spectrometer using the conventional stable isotope technique in the Department of Earth Sciences at the University of Oxford (Table S4).

\section{Results}

\subsection{Preservation, abundance, and diversity (nannofossils)}

All 41 samples yielded abundant calcareous nannofossils (Table S1). Preservation of the nannofossils varied between VG and $G$, but was predominantly $G$ in the majority of samples. A total of $\sim 115$ taxa were identified (see Taxonomic List in Supplement) with an average species richness of 65 species per sample (see Plates 1-6).

\subsection{Nannofossil biostratigraphy}

The Gault Clay samples are middle to late Albian in age and can be assigned to Nannofossil Zone BC24 through Subzone BC25b of Bown et al. (1998), based upon the following events in stratigraphic order (Fig. 3, Table S1): (i) presence of Tranolithus orionatus in the lowest sample (1.6 m); (ii) the FO of Axopodorhabdus albianus in the sample at $3.6 \mathrm{~m}$; (iii) the LO of Ceratolithina bicornuta in the sample at $9.0 \mathrm{~m}$; and (iv) the absence of Eiffellithus monechiae and E. turriseiffelii in the samples. The $21.4 \mathrm{~m}$ sampled section encompasses less than $3.14 \mathrm{Myr}$, using the absolute age of the base of T. orionatus $(110.73 \mathrm{Ma})$ and the base of E. monechiae (107.59 Ma) (Ogg and Hinnov, 2012). The sedimentation rate is therefore approximately $0.68 \mathrm{~cm} \mathrm{kyr}^{-1}$ (or $6.8 \mathrm{~m} \mathrm{Myr}^{-1}$ ) with an average temporal resolution of $\sim 78.5 \mathrm{kyr}$ per sample. A minor hiatus at the middle-upper Albian boundary based on missing ammonite zones and subzones (the upper part of Euhoplites lautus Zone and Anahoplites daviesi Subzone; Gale and Owen, 2010) likely represents less than 10$20 \mathrm{kyr}$ but is not apparent in the nannofossil biostratigraphy, which includes subzone $\mathrm{BC} 25 \mathrm{a}-\mathrm{BC} 25 \mathrm{~b}$ at this level (Bown et al., 1998).

\subsection{Distribution of major nannofossil taxa}

Eight nannofossil taxa have abundances that exceed 1-2\% in any sample (Biscutum constans, Zeugrhabdotus noeliae, Watznaueria barnesiae group, Lithraphidites carniolensis, Tranolithus orionatus, Prediscosphaera spp., Repagulum parvidentatum, Retecapsa spp.), with four taxa, Z. noeliae, 


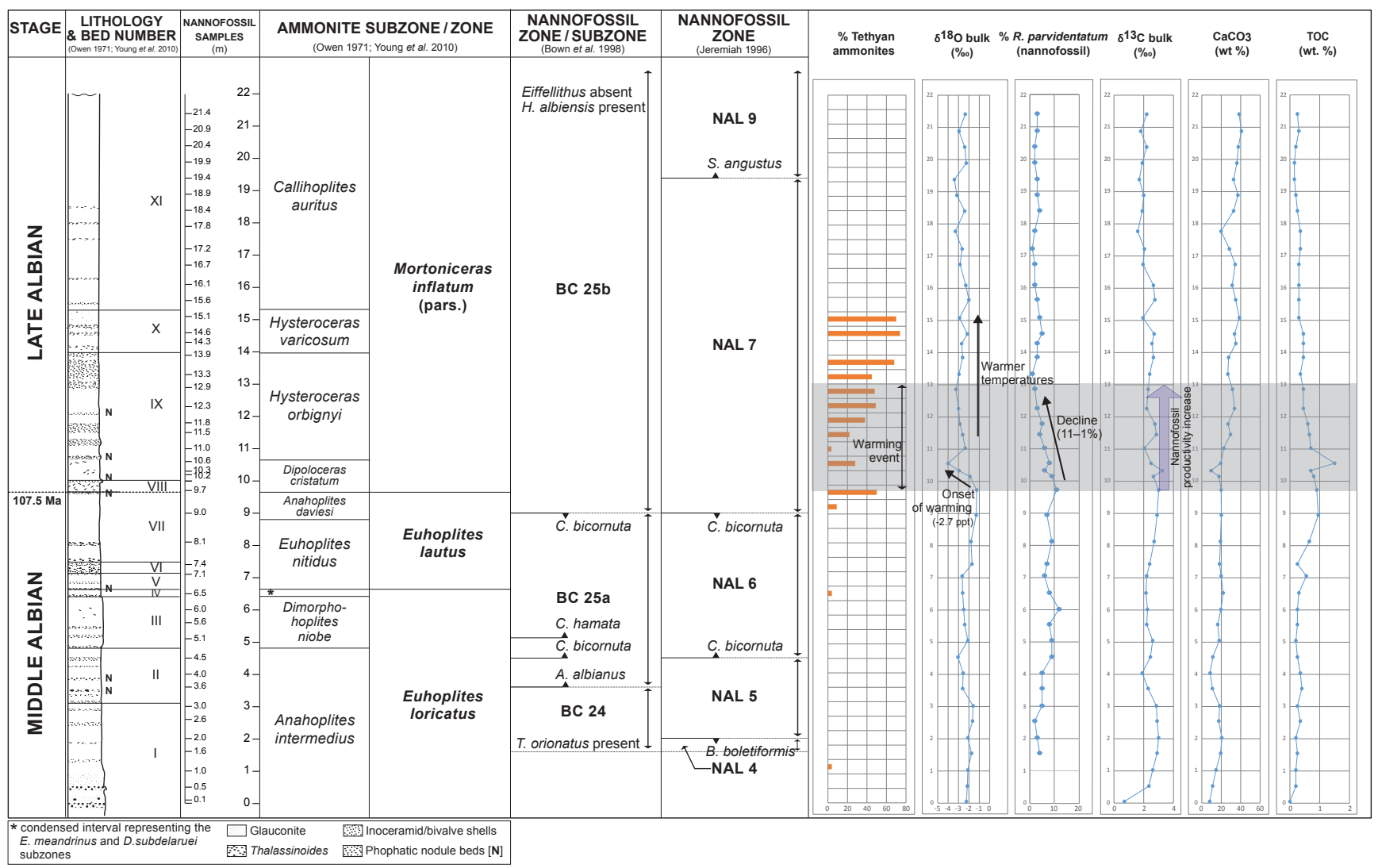

Figure 3. Sample details along with the ammonite zonation (Owen, 1971; Young et al., 2010), nannofossil biostratigraphy (Bown et al., 1998; Jeremiah, 1996), isotope geochemistry trends (bulk sediment carbon and oxygen isotope), carbonate $\left(\mathrm{CaCO}_{3}\right)$, and $\mathrm{TOC}_{\text {of }}$ the $\mathrm{Gault}$ Clay, Copt Point section. The early late Albian warming event is highlighted based on multi-proxy evidence from three independent datasets: nannofossils ( $R$. parvidentatum), Tethyan ammonites, and the $\delta^{18} \mathrm{O}_{\text {bulk }}$ record.

W. barnesiae group, B. constans, and $R$. parvidentatum, making up around $60 \%$ of the total assemblage (Fig. 4, Table S2). Z. noeliae (small Zeugrhabdotus spp.) is the most abundant species with a range of 9-41\% (mean $23 \%$ ), with peaks in Bed I (23\%), Beds IV-VI (28\%), lower Bed IX (35-41\%), Bed X (>25\%), and lower Bed XI (>25\%). The W. barnesiae group (including $W$. barnesiae and $W$. fossacincta) is the second most abundant taxon and fluctuates between 11 and $44 \%$ (mean $22 \%$ ) through the section. It shows abundance exceeding $40 \%$ in Bed IX in only one sample (at $10.3 \mathrm{~m}$ ). The $W$. barnesiae group shows weak negative correlations with both $B$. constans (correlation coefficient, $r=-0.39$ ) and $Z$. noeliae $(r=-0.58)$, indicating that its distribution is not wholly a result of closed-sum effects with the other two major taxa. The third major species, B. constans, shows relative abundances between 8 and $33 \%$ (mean 19\%) with significant peaks in Bed I ( $25 \%)$, Bed VI (22\%), upper Bed X, and through most of Bed XI (>20\%). The coolwater species $R$. parvidentatum varies in abundance from 1 to $12 \%$ (mean $4.9 \%$ ), with two sharp peaks at the top of Bed III (12\%) and in Bed VIII (11\%). A rapid decline in the abundance of $R$. parvidentatum is observed from Bed VIII into Bed IX, from 11 to $1 \%$. L. carniolensis (1-10\%; mean $4.6 \%)$, Prediscosphaera spp. (1-10\%; mean 5.2\%), Retecapsa spp. (1-3\%; mean 2\%), and T. orionatus (1-7\%; mean $3.8 \%$ ) are consistently present above $1-2 \%$ but do not show any clear abundance trends. D. ignotus (0-5\%, mean $1 \%), S$. laffittei (0-10\%, mean $2.5 \%)$, R. asper (0-2\%, mean $0.7 \%)$, Z. diplogrammus (0-3\%, mean $0.5 \%)$, and Z. howei $(0-7 \%$, mean $1.4 \%$ ) show low and variable abundances with no clear trends through the section.

\subsection{Productivity index}

To assess changes in surface water productivity, the nannofossil-based productivity index of Gale et al. (2000) was applied (Fig. 4, Table S2), using the ratio of the three taxa considered to represent eutrophs (Zeugrhabdotus and Biscutum) and generalists (Watznaueria):

$P($ productivity index $)=\left\lfloor\frac{\% \text { Zeug.spp. }+\% \text { Biscutum spp. }}{\% \text { Watz.spp. }}\right\rfloor$.

The productivity index $(P)$ exhibits a peak (4.9) in the upper part of Bed IX and shows higher values in Beds X and XI, 


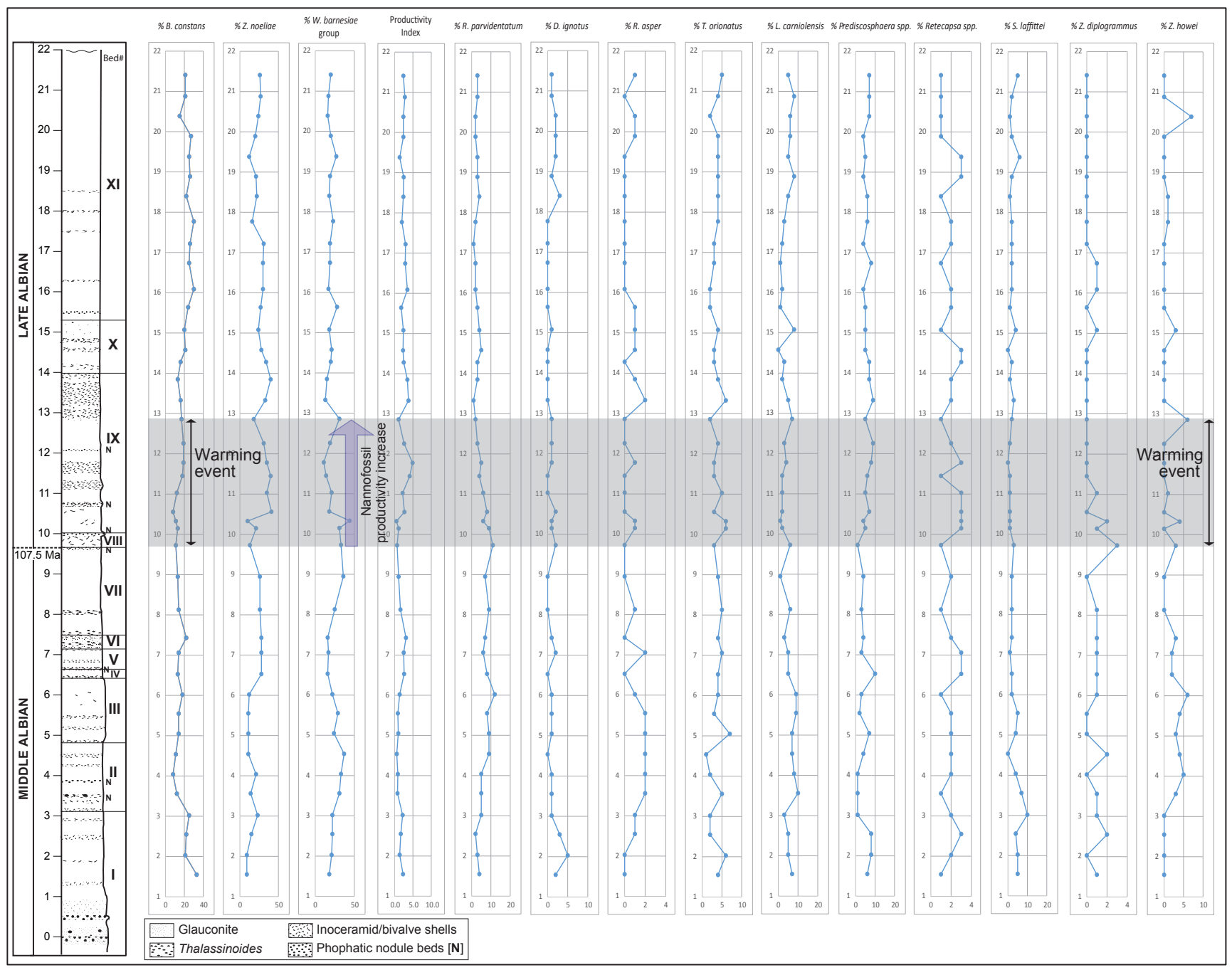

Figure 4. Nannofossil \% abundance trends of 13 taxa along with the calculated productivity index (Gale et al., 2000).

compared to the basal section (Beds I-VII). Overall, $P$ varies between 0.5 and 4.9 (mean 2.1) through the section.

\subsection{Ammonite distribution}

The $\%$ distribution of brancoceratid ammonites shows a clear correlation with the $\delta^{18} \mathrm{O}_{\text {bulk }}$ values with increased occurrences of four genera (Mojsisovicsia, Dipoloceras, Hysteroceras, and Mortoniceras) in Beds VIII to X (Fig. 3, Table S3). These taxa are virtually absent in the lower part of the section.

\subsection{Geochemistry $\left(\delta^{18} \mathrm{O}_{\text {bulk }}, \delta^{13} \mathrm{C}_{\text {bulk }}, \mathrm{CaCO}_{3}, \mathrm{TOC}\right)$}

Bulk oxygen isotope $\left(\delta^{18} \mathrm{O}_{\text {bulk }}\right)$ values show high variability in the Gault Clay section ( -1.3 to $4.0 \%$; mean $-2.5 \%$, standard deviation 0.57) (Fig. 3; Table S4). In Beds I-III, lower values are observed (mean $-2.2 \%$ ) that gradually become higher, reaching $-1.3 \%$ at the top of Bed VII.
In Bed IX (at $10.6 \mathrm{~m}$ ), a minimum value (negative peak) of $-4.0 \%$ is reached. Thereafter, values fluctuate between -2.0 and $-3.4 \%$ to the top of the section (Beds IX-XI). Despite the considerable variability, we consider the signal to be relatively free from diagenetic overprint due to the uniformly good fossil preservation and high diversity of nannofossils in the samples.

The bulk carbon isotope $\left(\delta^{13} \mathrm{C}_{\text {bulk }}\right)$ record is generally stable through the section, with fluctuations between 0.7 and $3.3 \%$ (mean 2.4\%o). The Lower Gault (mean 2.4\%o) and Upper Gault (mean $2.3 \%$ ) show closely similar values.

$\mathrm{CaCO}_{3}$ content varies between 8.1 and $40.9 \mathrm{wt} \%$ (mean $24.3 \mathrm{wt} \%$ ) and is significantly higher in the Upper Gault (Beds VIII-XI, mean 29.9wt \%) than the Lower Gault (Beds I-VII; mean $16.3 \%$ ). TOC content is generally low throughout the section $(<1.0 \mathrm{wt} \%)$ with a mean of $0.4 \mathrm{wt} \%$. Only one sample in Bed IX shows a maximum TOC of $1.5 \mathrm{wt} \%$. 


\section{Discussion}

\subsection{Macrofossil evidence for warming}

Southern-derived incursions of warm water ammonites were first noted in the middle and upper Albian of the Anglo-Paris Basin by Owen (1971, 1973). Brancoceratid ammonites are dominantly Tethyan in distribution and only appear sporadically in boreal latitudes during the lower and middle Albian, becoming common in the upper Albian (Owen, 1971; Kennedy and Cobban, 1976). Our results show that the percentages of four Gault Clay brancoceratid ammonite genera, Mojsisovicsia, Dipoloceras, Hysteroceras, and Mortoniceras increase dramatically in Bed VIII (from 9 to $50 \%$ ) coinciding with the negative excursion in $\delta^{18} \mathrm{O}_{\text {bulk }}$ values (Fig. 3). The flood of Dipoloceras spp. at the boundary of Beds VIIIIX is precisely coincident with a negative $\delta^{18} \mathrm{O}_{\text {bulk }}$ excursion (up to $-4.0 \%$ ). The abundance of Hysteroceras and Mortoniceras in Bed IX and Bed X (mean abundance: $45 \%$ ) coincides with relatively low $\delta^{18} \mathrm{O}_{\text {bulk values (mean }-2.8 \% \text { ). }}$

The influx of Tethyan ammonites coincident with the $\delta^{18} \mathrm{O}_{\text {bulk }}$ excursion in Bed VIII and Bed IX $(9.7-12.9 \mathrm{~m})$ is a good indication of the onset of an early late Albian warming event. It is also possible that the migration of Tethyan faunas into boreal provinces was facilitated by the late Albian sea level highstand (Hardenbol et al., 1998; Miller et al., 2011). Migration of Tethyan ammonites into the Anglo-Paris Basin may have occurred via intermittent flooding of low-lying European landmasses due to transgressions in the late Albian, but a route via the Atlantic Ocean was likely more permanent (Hancock, 1989).

A similar influx of Tethyan ammonites is also observed in the Lower Saxony Basin (northwestern Germany), where a rapid invasion of mainly mortoniceratids into the Hoplitinid Faunal Province coincides with the middle-upper Albian boundary. This change in fauna is reported to be indicated by a condensed interval (lower upper Albian) enriched in debris of inoceramids, phosphorite concretions, and ammonites in the Hannover-Lahe core from the Lower Saxony Basin (Lehmann et al., 2007).

\subsection{The isotopic palaeotemperature signal}

The $\delta^{18} \mathrm{O}_{\text {bulk }}$ values from the calcareous clay samples were most likely derived predominantly from nannofossils because scanning electron microscopy studies indicate that they constitute the major calcareous component in the Gault Clay (Young, 2010). The negative excursion of $2.7 \%$ (from -1.3 to $-4 \%$ o) recorded in Bed VIII and the lower part of Bed IX is not associated with any faunal indication of reduced salinity and, additionally, the $\delta^{13} \mathrm{C}_{\text {bulk }}$ values remain constant (2.5 to $3 \%$ ) through this interval (Fig. 3). Given the epicontinental basin setting, if there was a low salinity event as a result of freshwater run-off then a parallel reduction in $\delta^{13} \mathrm{C}_{\text {bulk }}$ values would be expected, which is not observed. However, the
$2.7 \%$ negative shift in $\delta^{18} \mathrm{O}_{\text {bulk }}$ values, if caused by temperature alone, would indicate a warming of approximately $12^{\circ} \mathrm{C}$ (Shackleton and Kennett, 1975), which is highly improbable. We suspect that a component of the low $\delta^{18} \mathrm{O}_{\text {bulk }}$ values registered at the level of Beds VIII-IX can be attributed to salinity, change in seasonality or water column depth, or vital effects.

A precisely coeval (basal Dipoloceras cristatum Ammonite Zone) and correlative warming event was identified in the expanded succession of the GB1 core from the Lower Saxony Basin, northwestern Germany (Erbacher et al., 2011). Here, $\delta^{18} \mathrm{O}$ values were obtained from exceptionally well-preserved (glassy) planktonic foraminifera and indicate a negative excursion of $2.1 \%$ within the basal $D$. cristatum Ammonite Zone. Mg / Ca ratios indicate that a significant part of this shift represents temperature change, interpreted as $6-7^{\circ} \mathrm{C}$. We use these calibrations of Erbacher et al. (2011) to constrain interpretation of our own data. If we attribute an equivalent part of the $\delta^{18} \mathrm{O}_{\text {bulk }}$ signal to changes in temperature, then in the middle Albian (0.1$3.6 \mathrm{~m}$, Bed I), surface water temperatures were moderate and ranged from approximately 23 to $27^{\circ} \mathrm{C}$. A significant fall to values of approximately $21^{\circ} \mathrm{C}$ is indicated through the middle Albian (3.6-9.7 m, Beds II-VII) and a major but brief warming event $(\sim 500 \mathrm{kyr})$ is evident in the early late Albian (above the middle-upper Albian boundary) in Bed VIII and Bed IX between 9.7 and $12.9 \mathrm{~m}$, during which temperatures reached $30^{\circ} \mathrm{C}$ (Fig. 3). Above this, in Beds X-XI, temperatures remained relatively constant at $25-28^{\circ} \mathrm{C}$. Bomou et al. (2016) recorded oxygen-isotope-derived palaeotemperatures from planktonic and benthonic foraminifera, shark teeth, and belemnites from the Gault Clay section at Wissant (Boulonnais area, France), approximately $40 \mathrm{~km} \mathrm{SE}$ of Folkestone. They considered the anomalously low oxygen isotope values obtained from foraminifera at some levels to be caused by diagenesis, supported by cathode luminescence study. However, their sea surface temperatures (Bomou et al., 2016, Fig. 7, p. 707) of $21-29^{\circ} \mathrm{C}$ correspond well with our values obtained from bulk sediment $\left(23-30^{\circ} \mathrm{C}\right)$.

\subsection{Nannofossil surface water palaeoenvironmental indicators}

Nannofossil species are typically broadly distributed across a range of marine photic zone environments but in some cases more specific palaeoecologies can be determined. These ecological preferences are typically determined using analysis of palaeobiogeographic distribution and by comparison with other palaeontological and geochemical environmental proxies. Repagulum parvidentatum is considered a robust indicator of cold water and this palaeoecology is one of the most strongly supported of any Mesozoic taxon, based upon striking palaeobiogeographic data from global datasets (e.g., Wise, 1983, 1988; Bown et al., 1998; Street and Bown, 2000; Kanungo, 2005; McAnena et al., 2013). It is typically only 


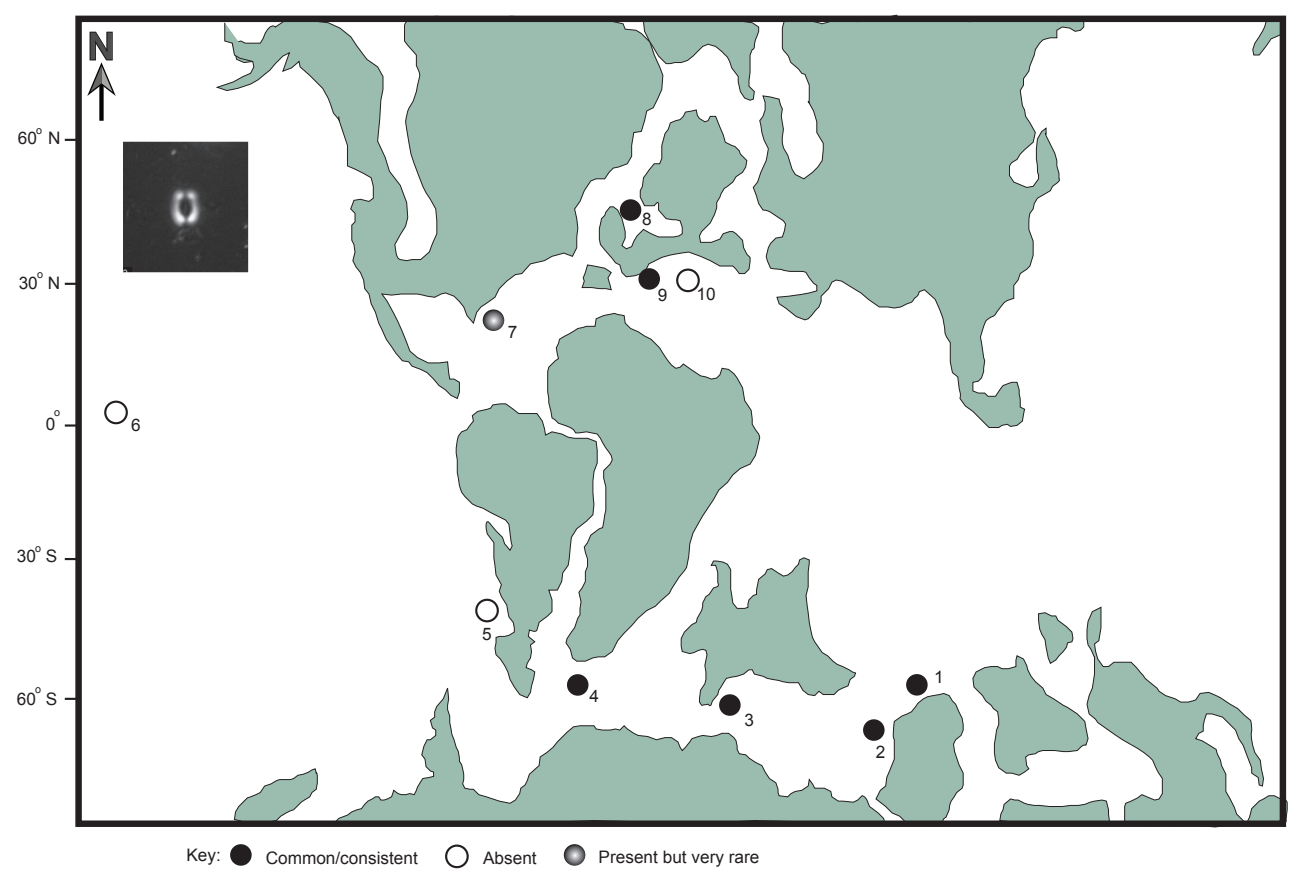

Figure 5. Bipolar distribution of $R$. parvidentatum during the mid-Cretaceous. Locations shown: 1 - Argo Abyssal Plain, Indian Ocean; 2 Naturaliste Plateau, Indian Ocean; 3 - Cauvery Basin, SE India; 4 - Falkland Plateau, Southern Ocean; 5 - Neuquén Basin, Argentina; 6 Shatsky Rise, Pacific Ocean; 7 - Blake Nose, western Atlantic; 8 - Gault Clay, England; 9 - Vocontian Basin, France; 10 - Umbria-Marche Basin, Italy. Data collated from Bown and Concheyro (2004), Erba (1987), Kanungo (2005), Lees (2002), and Wise (1988). Palaeogeographic reconstruction of the mid-Cretaceous is taken from Erbacher et al. (2001). Light microscope (LM) image of $R$. parvidentatum from the Gault Clay, Copt Point section (inset).

present at high-latitude boreal and austral sites and largely absent in the tropics and subtropics (Fig. 5). In our data, a rapid decline in the abundance of $R$. parvidentatum, from 11 to $1 \%$ is evident from 9.7 to $13.3 \mathrm{~m}$ (Figs. 3,4) and precisely coincides with the negative $\delta^{18} \mathrm{O}_{\text {bulk }}$ excursion, thus supporting the warming indicated by this proxy and the Tethyan ammonite influx. Similar trends in $R$. parvidentatum abundance from other Gault Clay sections in southern England support the regional decline in this taxon (Crux, 1991; Erba et al., 1992).

In addition to the palaeotemperature indications from the nannofossil assemblages, we are also able to make inferences on surface water productivity. The three most abundant nannofossil taxa in the Gault Clay are considered to be surface water fertility indicators, with $Z$. noeliae abundant under eutrophic conditions, B. constans abundant under mesotrophic conditions, and Watznaueria (W. barnesiae group) a dominant, generalist taxon with oligotrophic, lowfertility affinities (e.g., Roth and Bowdler, 1981; Roth and Krumbach, 1986; Thomsen, 1989; Erba, 1992; Fisher and Hay, 1999; Mutterlose and Kessels, 2000; Street and Bown, 2000; Giraud et al., 2003; Herrle et al., 2003; Linnert et al., 2010, 2011). The productivity index of Gale et al. (2000) was based on the assumption that Zeugrhabdotus and Biscutum were more responsive to eutrophic conditions than Watz- naueria and thus an index based on the relative abundance of these taxa would record productivity change. The limitations of this index are the following: (1) the abundance of Watznaueria, a robust taxon, increases with deteriorating preservation and (2) the closed-sum effects of interpreting percentage data. The index works best in well-preserved samples when the reciprocal relationship between these two sets of taxa can be shown as genuine rather than a closed-sum artefact. Nannofossil preservation is uniformly good in the Gault Clay and thus the productivity index values should be relatively independent of preservation influence.

The productivity index $(P)$ indicates a progressive rise in surface water fertility levels from Bed VIII $(\sim 9.7 \mathrm{~m}$ and above), with higher values in Bed IX through Bed XI (mean $P$, Beds VIII-XI $=2.5$ ). Beds I-VII of the Lower Gault exhibit lower values of the index (mean $P=1.6$ ). A large peak in productivity is indicated in Bed IX $(P=4.1-4.9,11.5-$ $11.8 \mathrm{~m}$ ), coinciding with the negative $\delta^{18} \mathrm{O}_{\text {bulk }}$ excursion and the inferred early late Albian warming event (Fig. 4), reflecting high percentages of $Z$. noeliae (35-40\%). B. constans shows relatively lower abundance (mean B. constans $=14 \%$ ) during the warming event (9.7-12.9 m, Beds VIII-IX), but increases thereafter and shows consistently higher percentages (mean B. constans $=23 \%$ ) in Beds X-XI. This suggests that the Gault Clay warming event in the late Albian was 


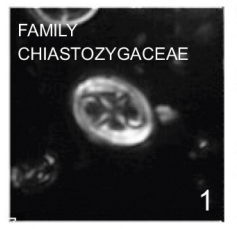

Staurolithites

gausorhethium F -0.3
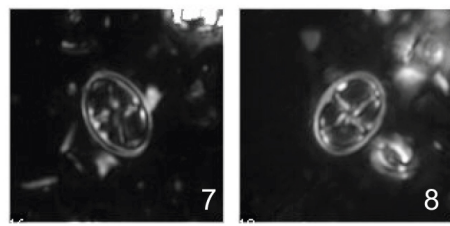

S. cf. S. angustus
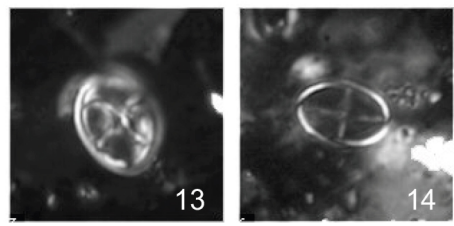

Staurolithites sp. 1
$\mathrm{~F}+0.5$
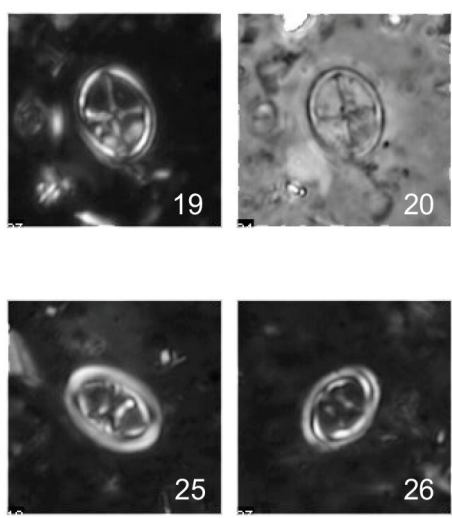

Z. xenotus $\mathrm{F}-4.5$

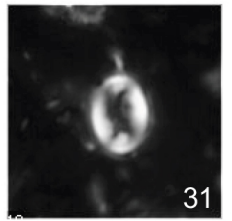

31

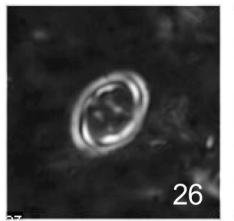

Z. xenotus $\mathrm{F}-4.5$
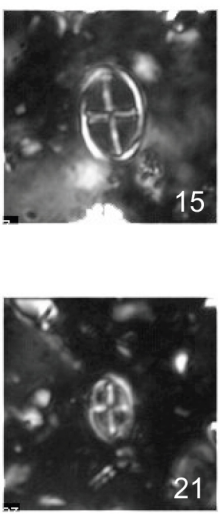

S. laffittei s. I
$\mathrm{F}+0.05$

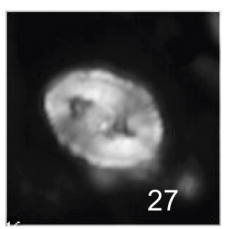

Z. biperforatus

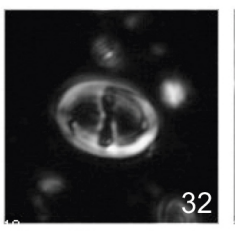

Trano $\mathrm{F}-0.3$
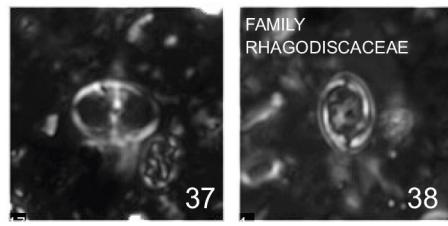

Percivalia
$\mathrm{F}+3.5$
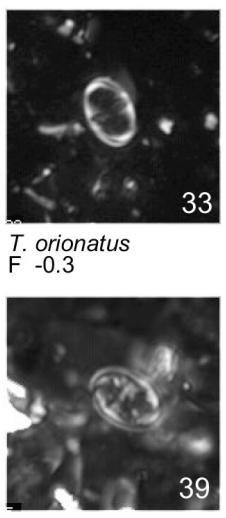

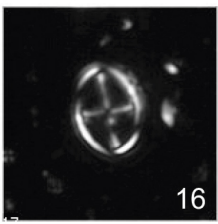

Staurolithites sp. 1

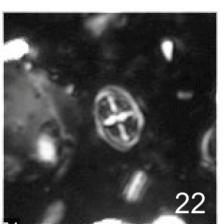

10
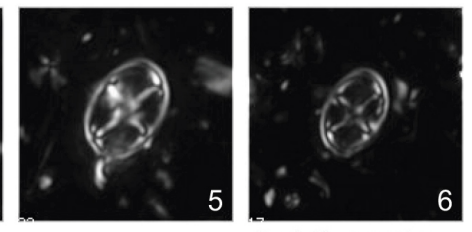

S. cf. S. angustus

F. ang

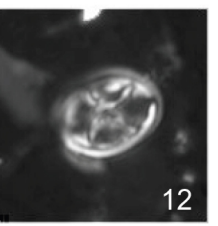

$\underset{\mathrm{F}+4}{\text { S. cf. S. rotatus }}$
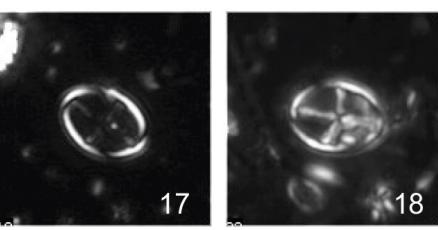

Staurolithites sp. 1
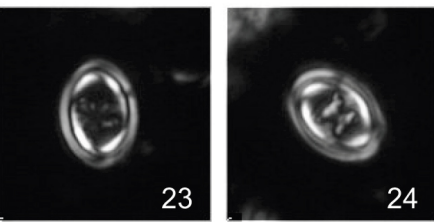

Zeugrhabdotus xenotus $\mathrm{F}-0.3$
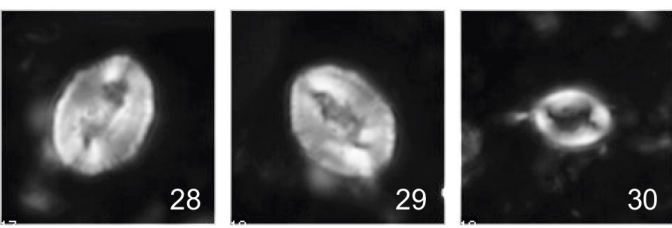

Z. cf. Z. biperforatus (small) $\mathrm{F}+3.5$
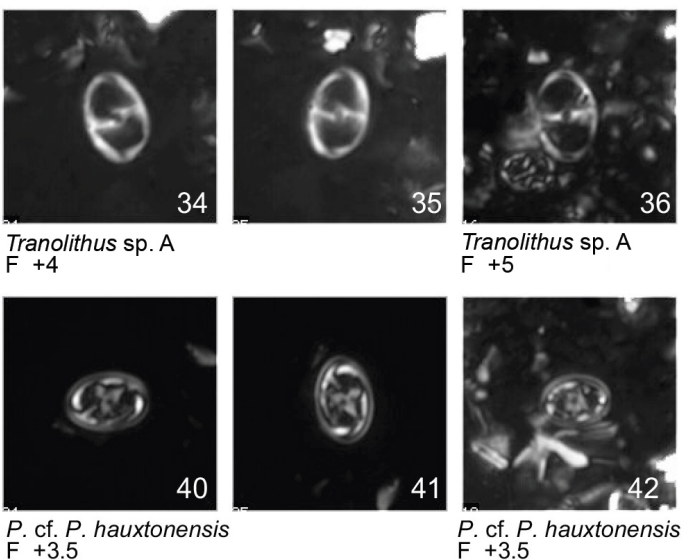

P. cf. $P$. hauxtonensis

$P$.
$\mathrm{F}+3.5$

$10 \mu \mathrm{m}$

Plate 1. Light microscope (LM) images of nannofossil taxa and their state of preservation (good to very good) in the studied samples. The LM images are reproduced at constant magnification with a $10 \mu \mathrm{m}$ scale bar at the bottom of each plate. The taxa are grouped according to families instead of alphabetical order. 

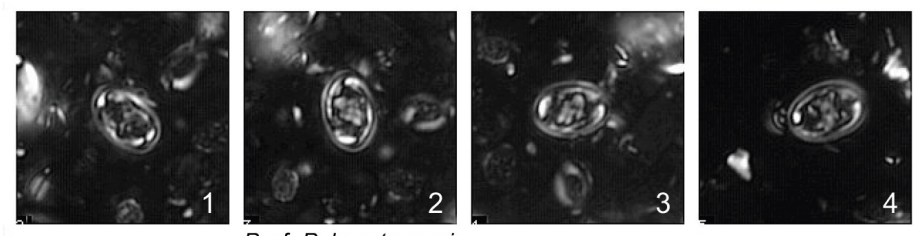

$P . \operatorname{cf} . P$.
$\mathrm{F}+0.7$
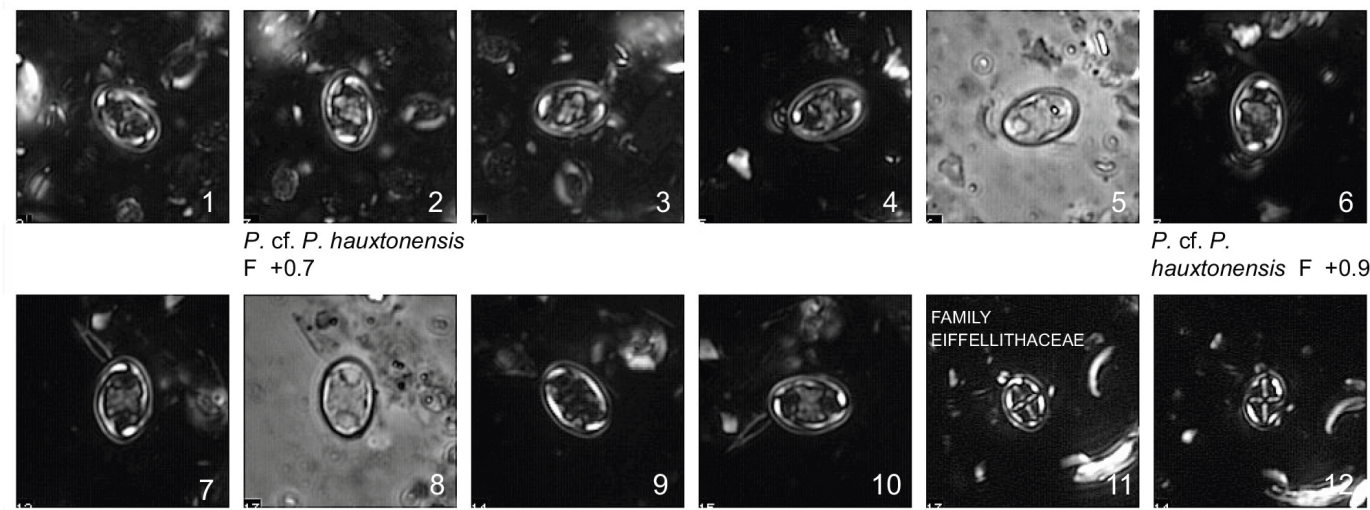

$P$. cf. $P$.

hauxtonensis $\mathrm{F}+0.9$
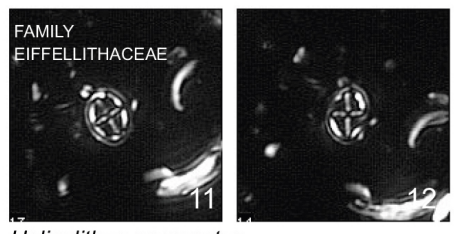

Helicolithus compactus
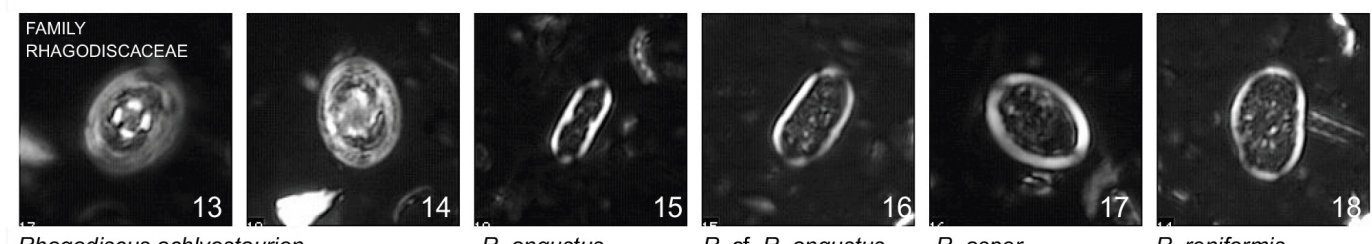
Rhagodiscu
$\mathrm{F}+0.35$

R. angustus
$\mathrm{F}+0.35$

R. cf. $R$. angustus

R. asper
$\mathrm{F}+0.5$

R. reniformis
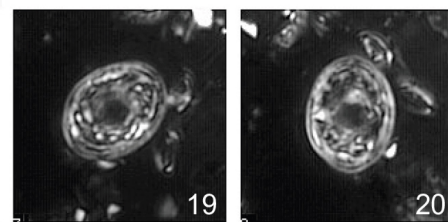

R. ham
$\mathrm{F}+1.5$

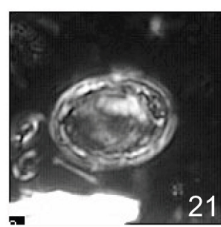

R. ham
$\mathrm{F}+2.5$
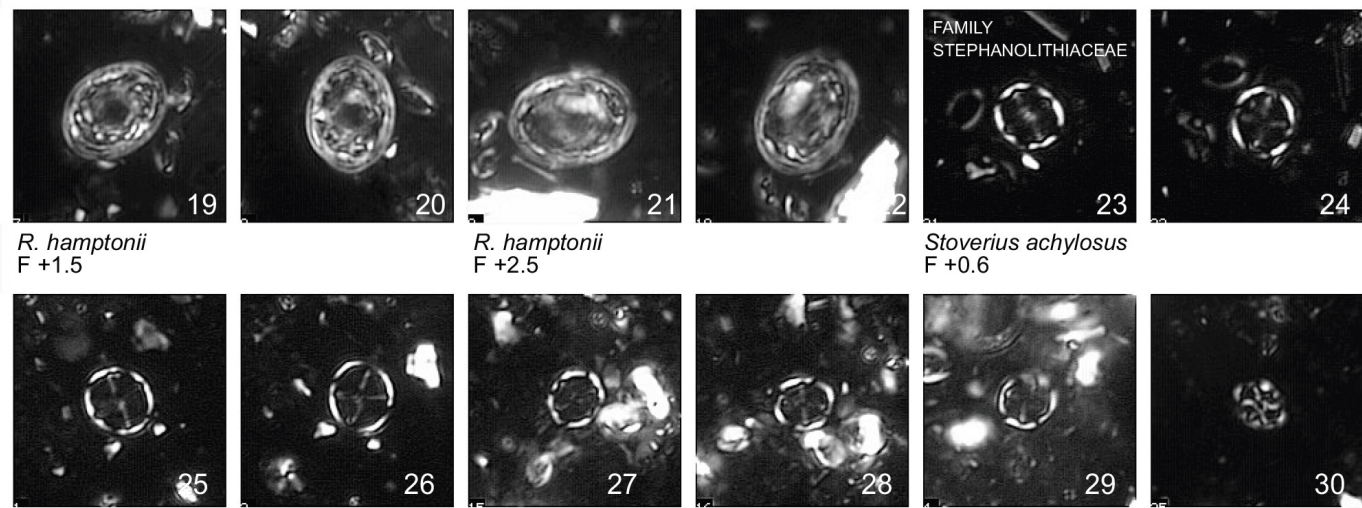

S. achylosus $\mathrm{F}+0.15$
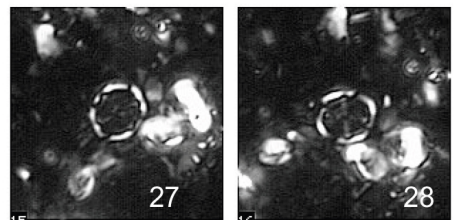

Stoverius protosignum

Stoverius
$\mathrm{F}+0.6$
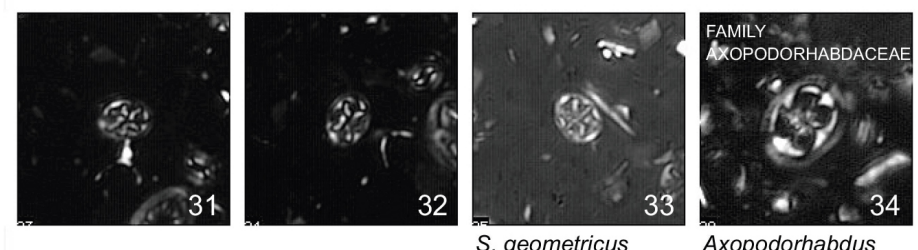

$\mathrm{F}+4.5$
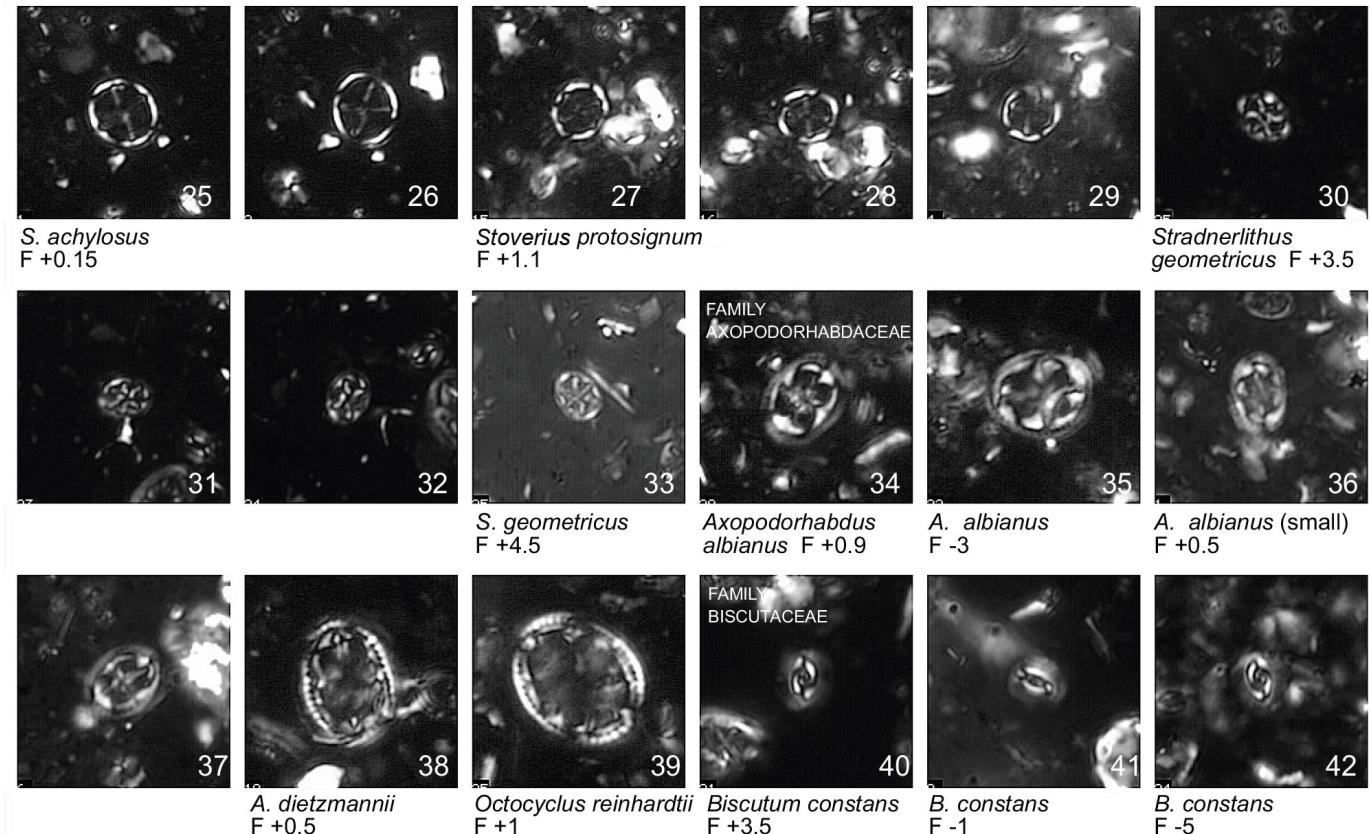

$\mathrm{F}-3$

$\mathrm{F}+0.5$
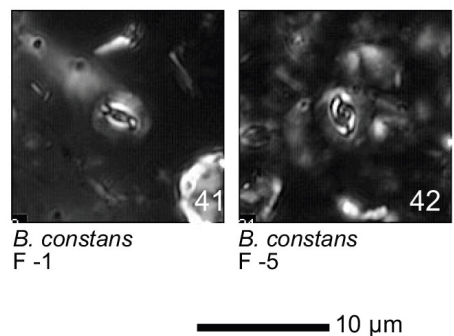

Plate 2. See caption of Plate 1. 

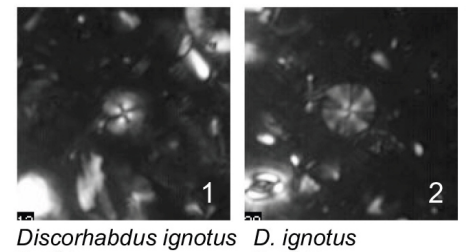

$\mathrm{F}+3.5$

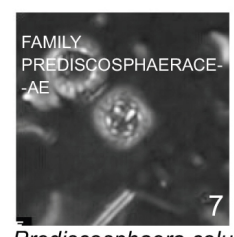

D. ignotus
$\mathrm{F}+3.5$

Prediscosphaera columnata
$\mathrm{F}+4$
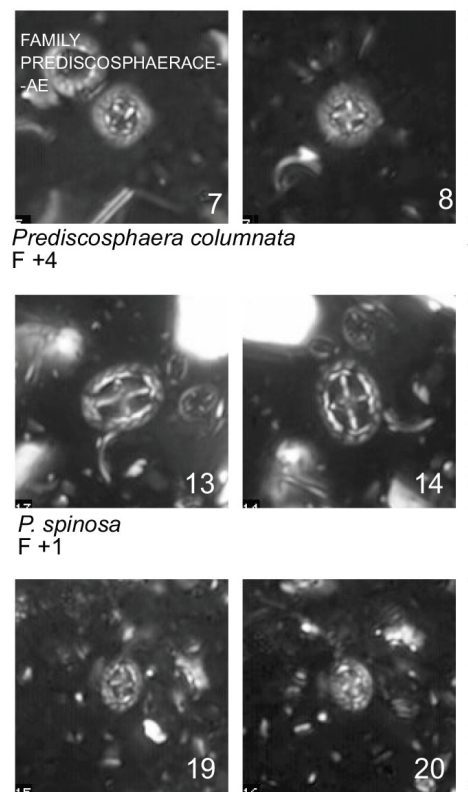

P. cf. P. spinosa (small) $\mathrm{F}+1$
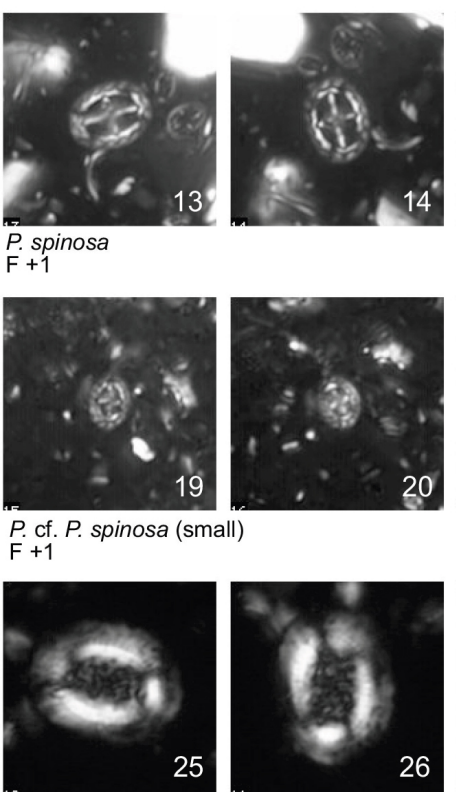

Gaarder
$\mathrm{F}+0.35$

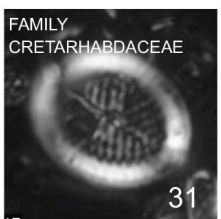

$$
\text { F }-4.5
$$
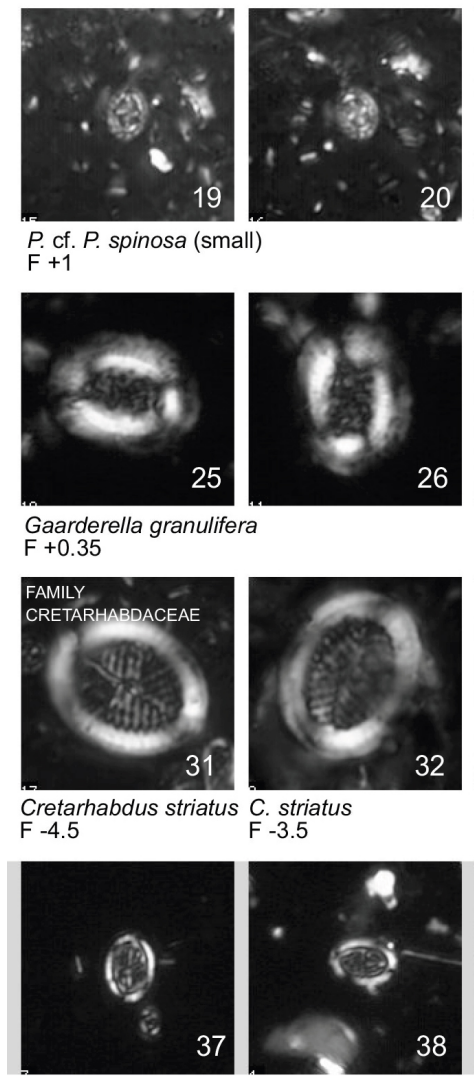

20

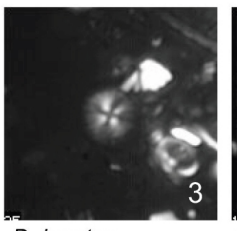

D. ignotus

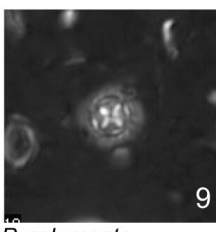

$P$. colut
F -5

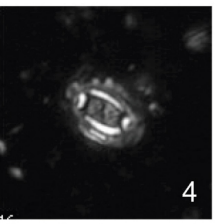

Seribisc

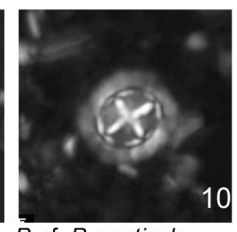

P. cf. P. ponticula

\section{Fin}
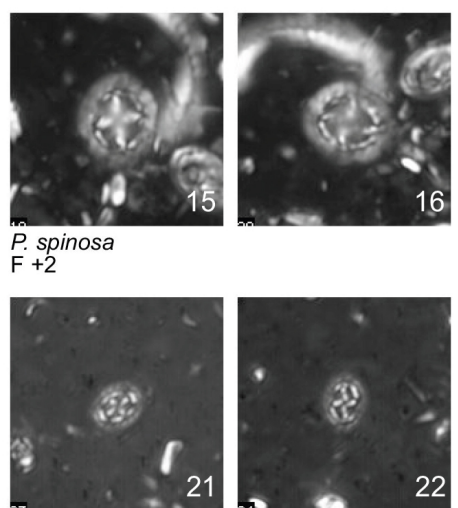

P. cf. $P$.
$\mathrm{F}+4$

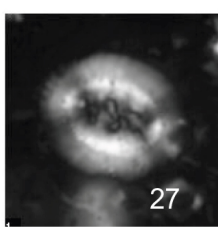

G. granulifera

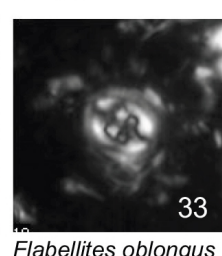

Flabellite
$\mathrm{F}+1$

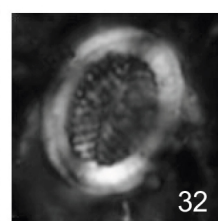

F. -3.5

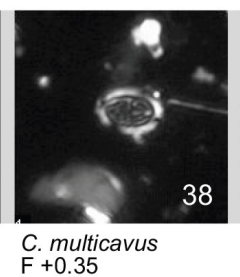

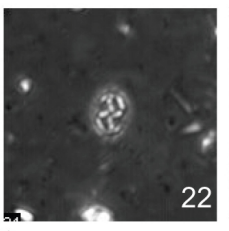

22

P. cf. P. spinosa (small)
$\mathrm{F}+4$

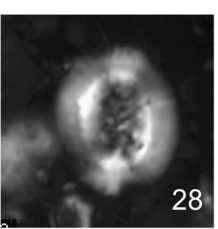

28

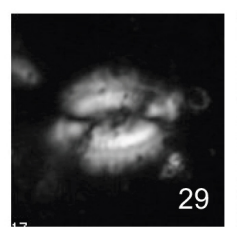

G. granulifera
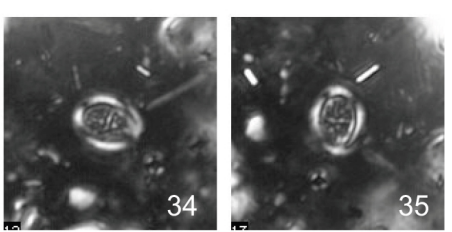

Cretarh
$\mathrm{F}+0.5$

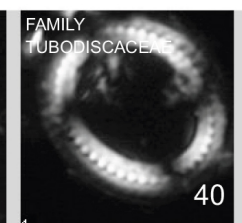

Manivitella
$\mathrm{F}+0.35$

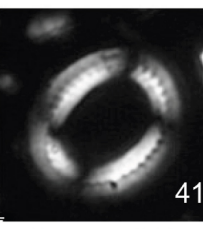

M. pem
$\mathrm{F}+0.35$

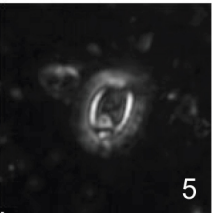

5

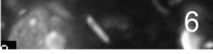

S. primitivum
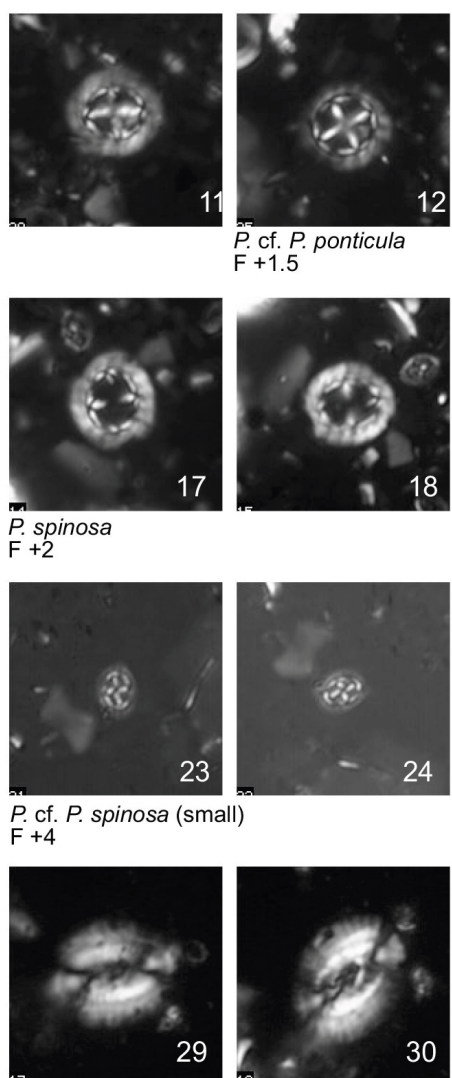

30

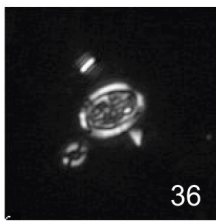

C. multicavus

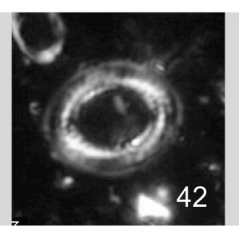

Manivitella sp. A $\mathrm{F}+0.35$

$10 \mu \mathrm{m}$

Plate 3. See caption of Plate 1. 


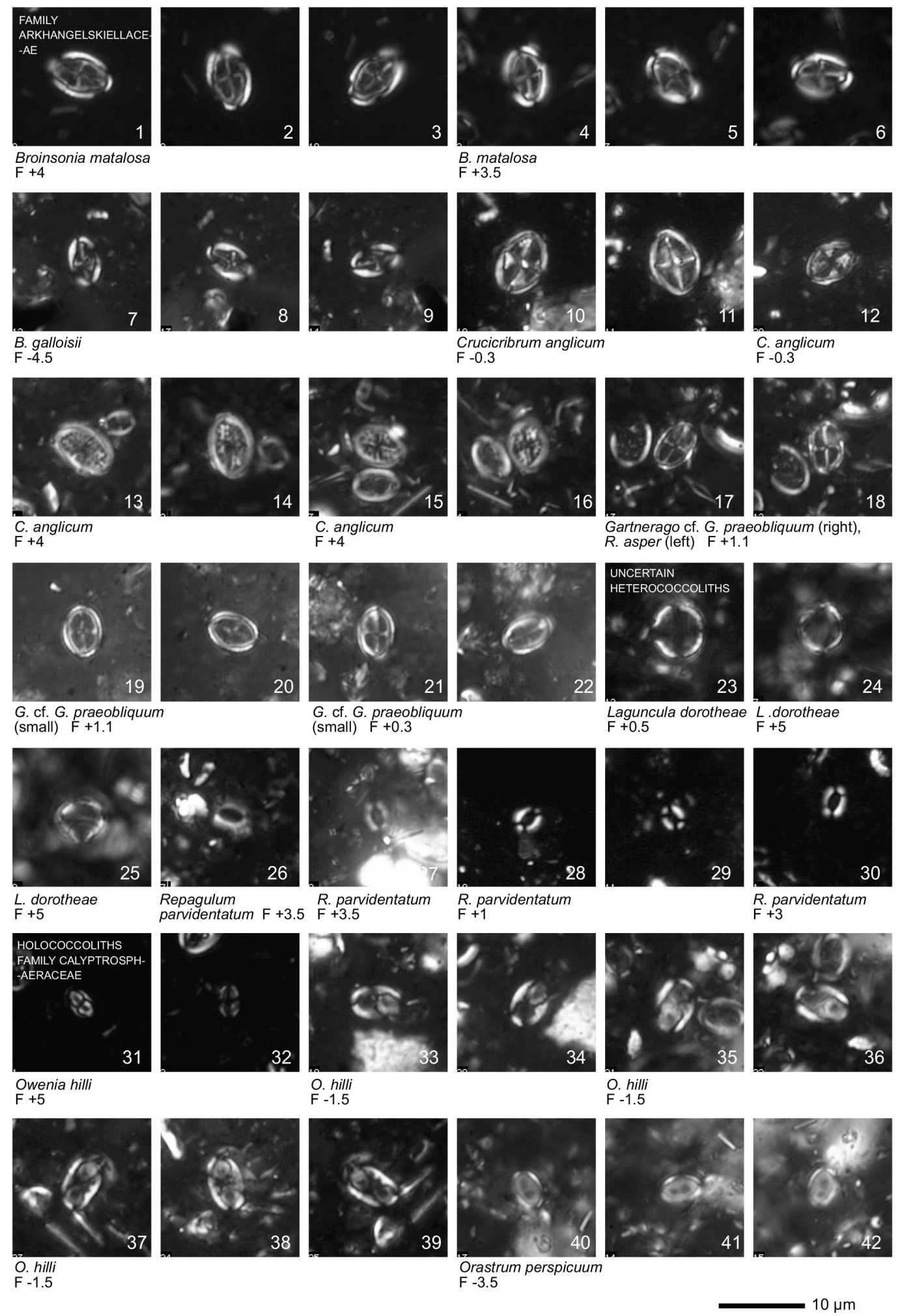

Plate 4. See caption of Plate 1. 


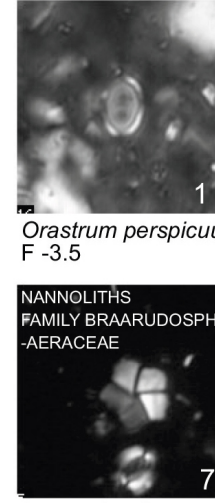

Braarudosphaera africana $\mathrm{F}+0.5$
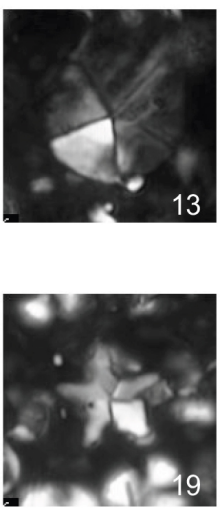

B. stenorhetha $\mathrm{F}+2$

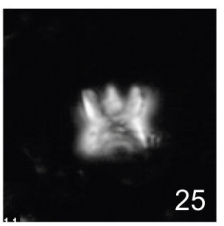

E. apertior?

(side-view) $\mathrm{F}+3.5$

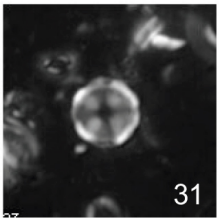

R. cf. R. planus

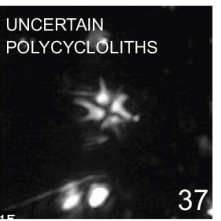

Hayesites albiensis F -0.3
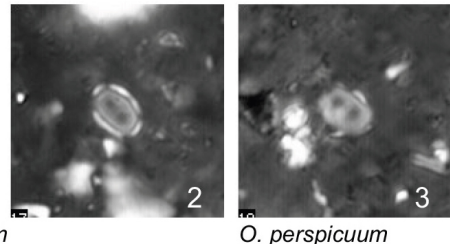

O. perspicuum

B. africana

B. cf. B. primula

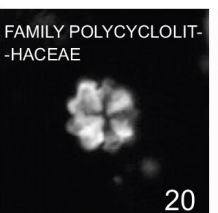

Eprolithus floralis

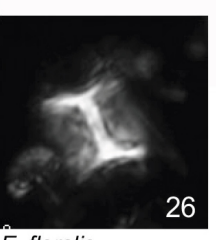

E. floralis

(side-view) F +5

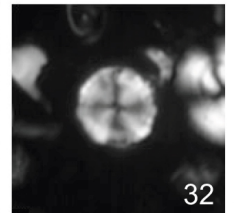

$R$. cf. R. planus

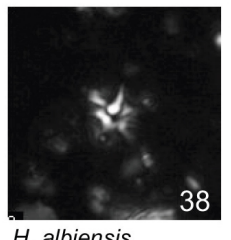

H. albiensis
$\mathrm{F}-0.3$

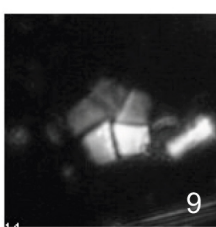

B. africana $\mathrm{F}+0.5$

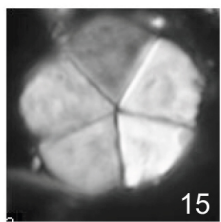

15

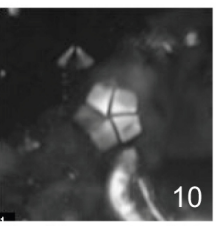

B. africana $\mathrm{F}+3.5$
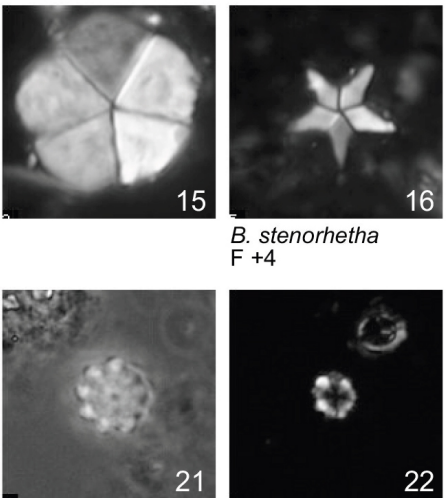

21
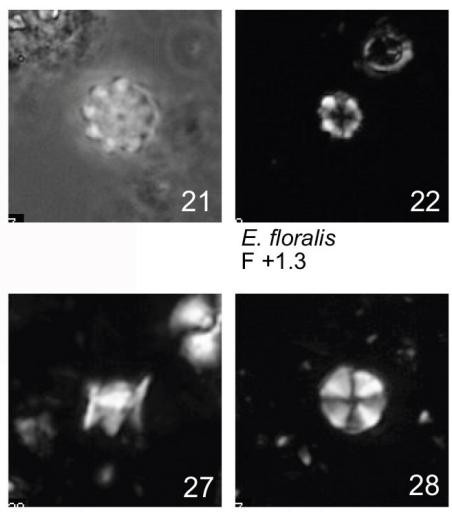

Eprolithus spp.

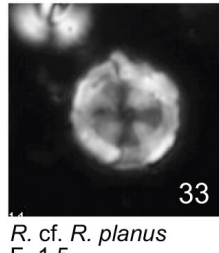

3

$\mathrm{F}-1.5$

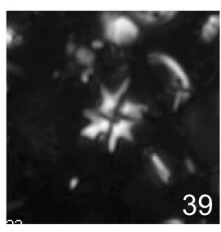

H. alb
$\mathrm{F}+4$

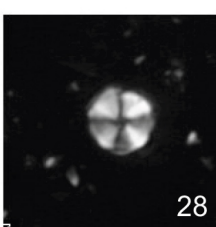

Radio
$\mathrm{F}+0.5$
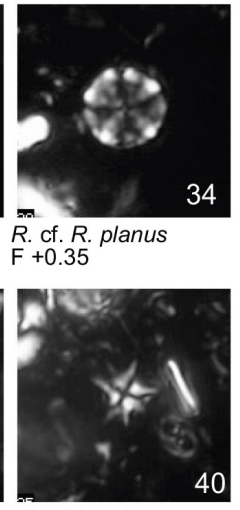

H. albiensis

40

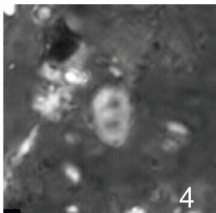

O. p
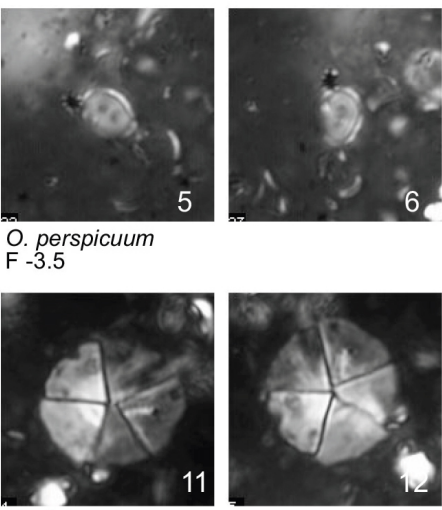

B. cf. B. primula
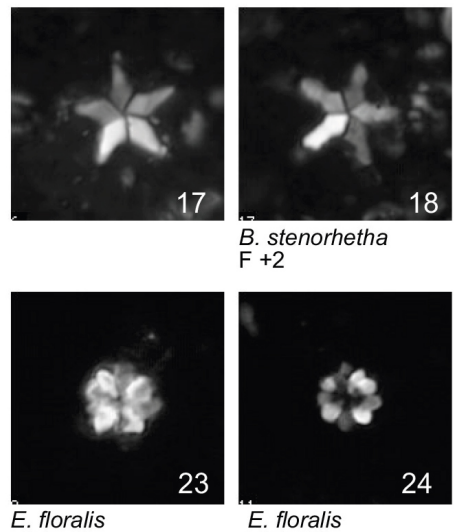

$\mathrm{F}+3$

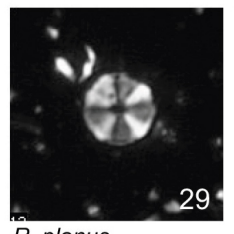

R. planus

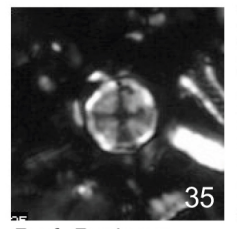

R. cf. R. planus

$+0.35$

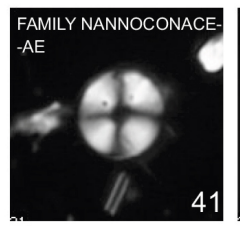

Nannonconus $\mathrm{x}-\mathrm{s}$
$\mathrm{F}-0.3$

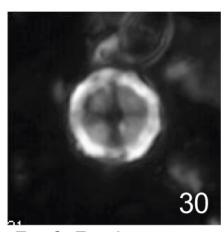

R. cf. R. planus
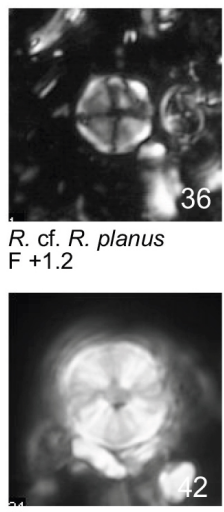

Nannonconus $\mathrm{x}-\mathrm{s}$
$\mathrm{F}-0.5$

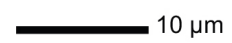

Plate 5. See caption of Plate 1. 

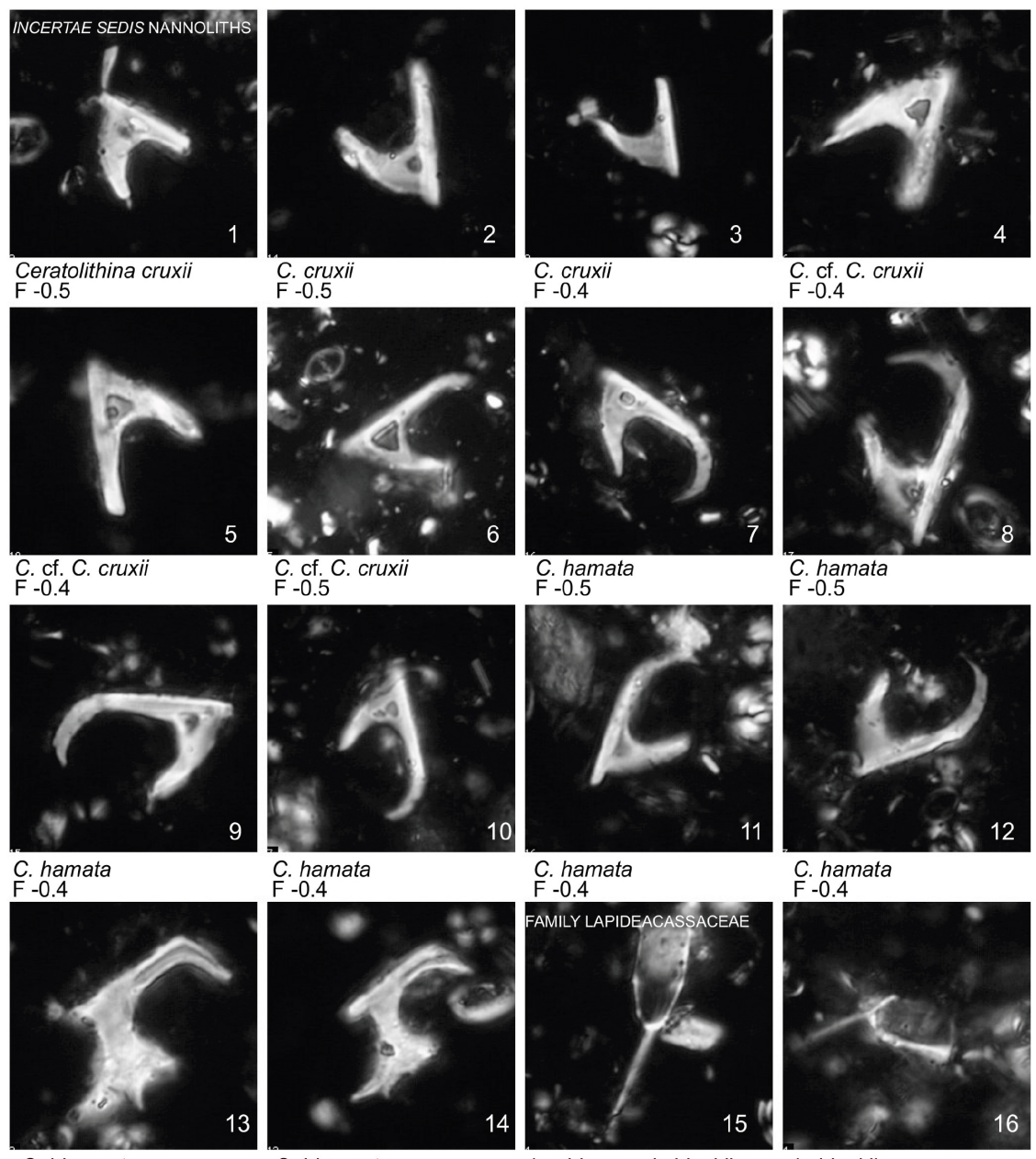

C. bicornuta

C. bicornuta

C. hamata F -0.4

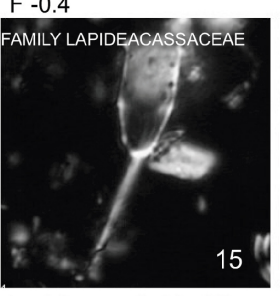

Lapideacassis blackii C. cf. C. cruxil

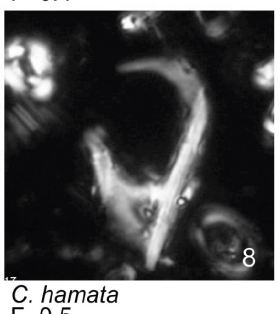

C. hamata
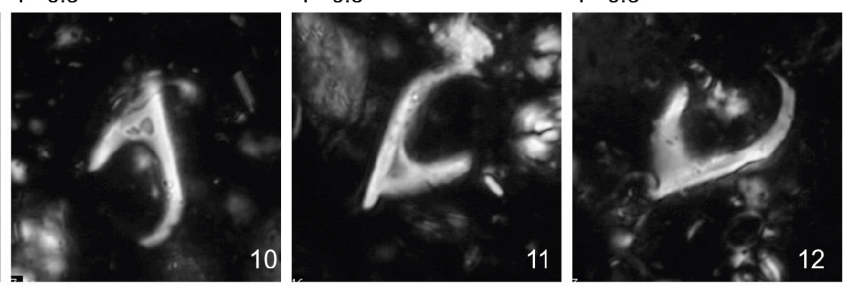

C. hamata

$-0.5$

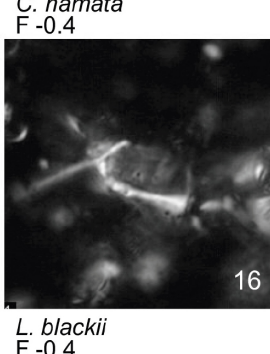

F. -0.4

$10 \mu \mathrm{m}$

Plate 6. See caption of Plate 1.

characterized initially by eutrophic conditions and peaks of $Z$. noeliae, followed by mesotrophic conditions with peaks of $B$. constans, although the ecological strategies of the two taxa have been suggested to be reversed in some cases (e.g., Fisher and Hay, 1999). Despite this, it is clear that a nannofossil productivity rise was coincident with the late Albian warming. It is also possible that surface water productivity levels began to rise just prior to the nannofossil response as $\delta^{13} \mathrm{C}_{\text {bulk }}(2.4-3.0 \%$ ) and TOC values (0.3-1.0 wt \%) start to rise in the upper part of the middle Albian (Bed VII, $\sim 7.4 \mathrm{~m}$; Fig. 3). The initial increase may reflect productivity in dinoflagellates and/or other planktonic organisms, followed by the warming and increase in nannofossil productivity in the early late Albian.

\subsection{Late Albian warming in the Gault Basin}

The congruent patterns shown by the $\delta^{18} \mathrm{O}_{\text {bulk }}$ data, Tethyan ammonite distributions, and abundance of $R$. parvidentatum provide good multi-proxy evidence to support the inference that temperature was a major control in the calcareous sedimentary record of the Gault Clay. A warming in excess of $6^{\circ} \mathrm{C}\left(6-7^{\circ} \mathrm{C}\right)$ appears to have promoted the occurrence of southern-derived, warm-water ammonites and caused a decline in the cool-water nannofossil $R$. parvidentatum.

A productivity peak shown in nannofossil abundance trends was coincident with the warming event and we speculate that this was linked to hydrological feedback mechanisms (Fenner, 2001; Erbacher et al., 2011; Friedrich et al., 2012). Numerical modelling studies based on isotope mass balance experiments provide strong evidence for an intensified Albian hydrologic cycle with increased humidity and precipitation fluxes, accompanied by higher wind strength, 
particularly in mid-latitudes to high latitudes $\left(34-75^{\circ} \mathrm{N}\right.$ palaeolatitude) of the Cretaceous Western Interior Basin (Ufnar et al., 2002). The calculated precipitation rates suggest that mid-latitude to high-latitude precipitation rates greatly exceeded modern rates $(\sim 200 \%$ greater in mid-latitudes and $\sim 100 \%$ greater at high latitudes; Ufnar et al., 2002). Additionally, intense humid conditions are believed to have triggered biogeochemical weathering rates and increased runoff, delivering more nutrients into basins (Föllmi, 2012). Increased run-off in the Gault Basin may have equally led to freshwater influxes of reduced salinity, influencing the $\delta^{18} \mathrm{O}$ signature to more negative values (Fisher and Arthur, 2002; Erbacher et al., 2011). However, because we do not see a parallel reduction in the $\delta^{13} \mathrm{C}_{\text {bulk }}$ values along with the $\delta^{18} \mathrm{O}_{\text {bulk }}$ values, it leads us to believe that the isotope trends observed in the Gault are controlled largely by temperature and that an intensified hydrologic cycle along with humid and stormy conditions invigorating nutrient fluxes are likely to be associated with the warming. The mechanism of latent atmospheric heat transport with the ingression of warm Tethyan surface waters from the superheated mid-Cretaceous tropics to boreal latitudes (Wilson et al., 2002; Erbacher et al., 2011) appears to be in agreement with our observations. The close agreement in timing and scale of warming between the Gault dataset and other boreal sections (e.g., Saxony Basin) suggest this was at least a regional increase in sea surface temperature and likely a response to mid-Cretaceous greenhouse gas forcing (Erbacher et al., 2011; Friedrich et al., 2012).

\section{Conclusions}

Quantitative nannofossil data, ammonite distributions, and bulk sediment carbon and oxygen stable isotope data suggest relatively dynamic surface water conditions during the middle-late Albian in the $\sim 22 \mathrm{~m}$ Gault Clay succession studied here. In the middle Albian (0.1-3.6 m), surface water temperatures appear to have been moderate $\left(23-27^{\circ} \mathrm{C}\right)$ based on $\delta^{18} \mathrm{O}_{\text {bulk }}$ values, with moderately elevated (mesotrophic) nannofossil productivity characterized by peaks of $B$. constans (mean $25 \%, 1.6-3.6 \mathrm{~m}$ ). This was followed by a cooling trend (middle Albian; 3.6-9.7 m) with temperatures around $21^{\circ} \mathrm{C}$. The cooling was followed by a warming event lasting $\sim 500 \mathrm{kyr}\left(9.7-12.9 \mathrm{~m} ; 30^{\circ} \mathrm{C}\right)$ in the early late Albian (above the middle-upper Albian boundary), evidenced by a $\delta^{18} \mathrm{O}_{\text {bulk }}$ negative excursion, alongside a rapid abundance decline of the cool-water nannofossil species $R$. parvidentatum (from 11 to $1 \%$ ) and influxes of southern-sourced Tethyan ammonites in Bed VIII of the Gault Clay. The warming appears to have been accompanied by relatively higher nannofossil productivity, shown by high percentages $(\sim 40 \%)$ of $Z$. noeliae, with the productivity index reaching maximum values of up to 4.9 at the peak of warming $(11.8 \mathrm{~m}$, Bed IX, early late Albian). Temperatures in the late Albian $\left(25-28^{\circ} \mathrm{C}\right)$ remained higher than the middle Albian, accom- panied by mesotrophic conditions as shown by higher percentages of B. constans (20-25\%).

The most compelling argument for the early late Albian warming event is the convergence of three independent datasets: nannofossils, ammonites, and bulk sediment carbon and oxygen stable isotopes. We interpret that the $\delta^{18} \mathrm{O}_{\text {bulk values were derived predominantly from nannofos- }}$ sils as they constitute the major calcareous component in the Gault Clay observed under scanning electron microscopy. We do not see evidence of reduced salinity significantly influencing the negative $\delta^{18} \mathrm{O}_{\text {bulk }}$ excursion, either through the $\delta^{13} \mathrm{C}_{\text {bulk }}$ record, which shows stable values, or in the marine assemblages (ammonites and nannofossils). However, the $2.7 \%$ negative shift in the $\delta^{18} \mathrm{O}_{\text {bulk }}$ values, if caused by temperature alone, would indicate a warming of approximately $12^{\circ} \mathrm{C}$ (Shackleton and Kennett, 1975), which seems unlikely. Therefore, we suspect that a component of the low $\delta^{18} \mathrm{O}_{\text {bulk }}$ values observed in Beds VIII-IX is attributable to some other factor, such as a change in seasonality or water column depth at the peak of nannofossil production or vital effects. The magnitude of warming estimated herein (6$7^{\circ} \mathrm{C}$ ) is comparable with other studies (Erbacher et al., 2011; Friedrich et al., 2012). During this time, relatively warmer and humid climates may have enhanced run-off from the hinterland thereby increasing nutrient input to the shallow epicontinental Gault basin. This could explain the shift in abundance of nannofossil species that are characteristic of elevated fertility (B. constans and $Z$. noeliae) through the studied section. The late Albian highstand and sea level rises (Hardenbol et al., 1998; Miller et al., 2011) may also have led to improved marine connections and the opening of gateways that further facilitated the southern-sourced ammonite migration and established the nanoplankton populations that we have observed in the Gault Clay.

Data availability. All underlying datasets pertaining to this article are provided in the Supplement. The nannofossil slides can be accessed through Paul Bown at University College London.

Supplement. The supplement related to this article is available online at: https://doi.org/10.5194/jm-37-231-2018-supplement.

Competing interests. The authors declare that they have no conflict of interest.

Acknowledgements. Sudeep Kanungo is a former recipient of the Thomas Witherden Batt Scholarship and Overseas Research Scholarship (UCL Graduate School) that funded this study. We thank the reviewers Fabienne Giraud and Emanuela Mattioli and the anonymous referee for improving the paper significantly with constructive suggestions and questions. Thanks are due to the Oxford University laboratory for generating the isotope geochemistry 
data used in this study. Sudeep Kanungo acknowledges Jim Davy and Jayne Dunn (UCL) for helping with sample collection and Christopher Kesler (EGI) for improving the maps. Last but not least, special thanks to Gosia Skowron (EGI) for redrafting the figures with care and precision.

Edited by: Emanuela Mattioli

Reviewed by: Fabienne Giraud, Emanuela Mattioli and one anonymous referee

\section{References}

Bomou, B., Deconinck, J.-F., Pucéat, E., Amédro, F., Joachimski, M. M., and Quillévéré, F.: Isotopic seawater temperatures in the Albian Gault Clay of the Boulonnais (Paris Basin): palaeoenvironmental implications, P. Geologist. Assoc., 127, 699-711, 2016.

Bown, P. R. and Concheyro, A.: Lower Cretaceous calcareous nannoplankton from the Neuquén Basin, Argentina, Mar. Micropaleontol., 52, 51-84, 2004.

Bown, P. R. and Young, J. R.: Techniques, in: Calcareous Nannofossil Biostratigraphy, edited by: Bown, P. R., Kluwer Academic, Cambridge University Press, 16-28, 1998.

Bown, P. R., Rutledge, D., Crux, J. A., and Gallagher, L. T.: Lower Cretaceous, in: Calcareous Nannofossil Biostratigraphy, edited by: Bown, P. R., Kluwer Academic, Cambridge University Press, 86-131, 1998.

Casey, R.: The stratigraphical palaeontology of the Lower Greensand, Palaeontology, 3, 487-621, 1961.

Coccioni, R., Sabatino, N., Frontalini, F., Gardin, S., Sideri, M., and Sprovieri, M.: The neglected history of Oceanic Anoxic Event 1b: insights and new data from the Poggio le Guaine section (Umbria-Marche Basin). Stratigraphy, 11, 245-282, 2014.

Crux, J. A.: Albian calcareous nannofossils from the Gault Clay of Munday's Hill (Bedfordshire, England), J. Micropalaeontology, 10, 203-221, https://doi.org/10.1144/jm.10.2.203, 1991.

Erba, E.: Mid-Cretaceous cyclic pelagic facies from the UmbriaMarche Basin: What do calcareous nannofossils suggest?, INA Newsletter, 9, 52-53, 1987.

Erba, E.: Middle Cretaceous calcareous nannofossils from the western Pacific (Leg 129): Evidence for paleoequatorial crossings, Proceedings of the ODP, Scientific Results, 129, 189-201, 1992.

Erba, E., Castradori, D., Guasti, G., and Ripepe, M.: Calcareous nannofossils and Milanktovitch cycles: the example of the Albian Gault Clay Formation (Southern England), Palaeogeogr. Palaeocl., 93, 47-69, 1992.

Erbacher, J., Hemleben, C., Huber, B. T., and Markey, M.: Correlating environmental changes during early Albian oceanic anoxic event 1B using benthic foraminiferal paleoecology, Mar. Micropaleontol., 38, 7-28, 1999.

Erbacher, J., Huber, B. T., Norris, R. D., and Markey, M.: Increased thermohaline stratification as a possible cause for an oceanic anoxic event in the Cretaceous period, Nature, 409, 325-327, 2001.

Erbacher, J., Friedrich, O., Wilson, P. A., Lehmann, J., and Weiss, W.: Short-term warming events during the boreal Albian (mid-Cretaceous), Geology, 39, 223-226, https://doi.org/10.1130/G31606.1, 2011.
Fenner, J.: Middle and Late Albian geography, oceanography, and climate and the setting of the Kirchrode I and II borehole sites, Palaeogeogr. Palaeocl., 174, 5-32, 2001.

Fisher, C. G. and Arthur, M. A.: Water mass characteristics in the Cenomanian US Western Interior seaway as indicated by stable isotopes of calcareous organisms, Palaeogeogr. Palaeocl., 188, 189-213, 2002.

Fisher, C. G. and Hay, W. W.: Calcareous nannofossils as indicators of mid-Cretaceous paleofertility along an ocean front, U. S. Western Interior. Geol. S. Am. S., 332, 161-180, 1999.

Föllmi, K. B.: Early Cretaceous life, climate and anoxia, Cretaceous Res., 35, 230-257, https://doi.org/10.1016/j.cretres.2011.12.005, 2012.

Friedrich, O., Norris, R. D., and Erbacher, J.: Evolution of middle to Late Cretaceous oceans - A 55 m.y. record of Earth's temperature and carbon cycle, Geol. Soc. Am., 40, 107-110, https://doi.org/10.1130/G32701.1, 2012.

Gale, A. S. and Owen, H. G.: Introduction to the Gault, in: Fossils of the Gault Clay, edited by: Young, J. R., Gale, A. S., Knight, R. I., and Smith, A. B., Palaeontological Association Field Guide to Fossils, 12, 1-16, 2010.

Gale, A. S., Smith, A. B., Monks, N. E. A., Young, J. A., Howard, A., Wray, D. S., and Huggett, J. M.: Marine biodiversity through the Late Cenomanian-Early Turonian: palaeoceanographic controls and sequence stratigraphic biases, J. Geol. Soc. London, 157, 745-757, 2000.

Galeotti, S., Sprovieri, M., Coccioni, R., Bellanca, A., and Neri, R.: Orbitally modulated black shale deposition in the upper Albian Amadeus Segment (central Italy): a multi-proxy reconstruction, Palaeogeogr. Palaeocl., 190, 441-458, 2003.

Giraud, F., Olivero, D., Baudin, F., Reboulet, S., Pittet, B., and Proux, O.: Minor changes in surface-water fertility across the oceanic anoxic event 1d (latest Albian, SE France) evidenced by calcareous nannofossils, Int. J. Earth Sci., 92, 267-284, 2003.

Hancock, J. M.: Sea-level changes in the British region during the Late Cretaceous, P. Geologist. Assoc., 100, 565-594, 1989.

Hardenbol, J., Thierry, J., Farley, M. B., Jacquin, Th., de Graciansky, P.-C., and Vail, P. R.: Mesozoic and Cenozoic sequence chronostratigraphic framework of European basins, in: Mesozoic-Cenozoic Sequence Stratigraphy of European Basins, edited by: de Graciansky, P.-C., Hardenbol, J., Jacquin, Th., and Vail, P. R., SEPM Spec. P., 60, 3-13, 763-781 (and chart supplements), 1998.

Herrle, J. O. and Mutterlose, J.: Calcareous nannofossils from the Aptian-early Albian of SE France: paleoecological and biostratigraphic implications, Cretaceous Res., 24, 1-22, 2003.

Herrle, J. O., Pross, J., Friedrich, O., Kößler, P., and Hemleben, C.: Forcing mechanisms for mid-Cretaceous black shale formation: evidence from the Upper Aptian and Lower Albian of the Vocontian Basin (SE France), Palaeogeogr. Palaeocl., 190, 399-426, 2003.

Herrle, J. O., Kößler, P., Friedrich, O., Erlenkeuser, H., and Hemleben, C.: High-resolution carbon isotope records of the Aptian to Lower Albian from SE France and the Mazagan Plateau (DSDP Site 545): a stratigraphic tool for paleoceanographic and paleobiologic reconstruction, Earth Planet. Sc. Lett., 218, 149161, 2004.

Herrle, J. O., Schröder-Adams, C. J., Davis, W., Pugh, A. T., Galloway, J. M., and Fath, J.: Mid-Cretaceous High Arctic Stratig- 
raphy, Climate, and Oceanic Anoxic Events, Geology, 43, 403406, https://doi.org/10.1130/G36439.1, 2015.

Huber, B. T. and Leckie, R. M.: Planktic foraminiferal species turnover across deep-sea Aptian/Albian boundary sections, J. Foramin. Res., 41, 53-95, 2011.

Jenkyns, H. C.: Geochemistry of oceanic anoxic events, Geochem. Geophy. Geosy., 11, Q03004, https://doi.org/10.1029/2009GC002788, 2010.

Jeremiah, J.: A proposed Albian to Lower Cenomanian nannofossil biozonation for England and the North Sea Basin, J. Micropalaeontology, 15, 97-129, https://doi.org/10.1144/jm.15.2.97, 1996.

Kanungo, S.: Biostratigraphy and palaeoceanography of midCretaceous calcareous nannofossils: studies from the Cauvery Basin, SE India; the Gault Clay Formation, SE England; ODP Leg 171B, western North Atlantic and ODP Leg 198, NW Pacific Ocean, $\mathrm{PhD}$ thesis, University College London, London, 260 pp., 2005.

Kennedy, W. J. and Cobban, W. A.: Aspects of ammonite biology, biogeography, and biostratigraphy, Special Papers in Palaeontology no. 17, 94 pp., 1976.

Knight, R. I.: Phosphates and phosphogenesis in the Gault Clay (Albian) of the Anglo-Paris Basin, Cretaceous Res., 20, 507-521, 1999.

Lees, J. A.: Calcareous nannofossil biogeography illustrates palaeoclimate change in the Late Cretaceous Indian Ocean, Cretaceous Res., 23, 537-634, 2002.

Leckie, R. M., Bralower, T. J., and Cashman, R.: Oceanic anoxic events and plankton evolution: Biotic response to tectonic forcing during the mid-Cretaceous, Palaeoceanography, 17, 13-1-1329, https://doi.org/10.1029/2001PA000623, 2002.

Lehmann, J., Friedrich, O., Luppold, F. W., Weiß, W., and Erbacher, $\mathrm{J} .:$ Ammonites and associated macrofauna from around the Middle/Upper Albian boundary of the Hannover-Lahe core, northern Germany, Cretaceous Res., 28, 719-742, 2007.

Li, X., Wei, Y., Li, Y., and Zhang, C.: Carbon isotope records of the early Albian oceanic anoxic event (OAE) 1b from eastern Tethys (southern Tibet, China), Cretaceous Res., 62, 109-121, https://doi.org/10.1016/j.cretres.2015.08.015, 2016.

Linnert, C., Mutterlose, J., and Erbacher, J.: Calcareous nannofossils of the Cenomanian/Turonian boundary interval from the Boreal Realm (Wunstorf, northwest Germany), Mar. Micropaleontol., 74, 38-58, 2010.

Linnert, C., Mutterlose, J., and Mortimore, R.: Calcareous nannofossils from Eastbourne (Southeastern England) and the paleoceanography of the Cenomanian-Turonian boundary interval, Palaios, 26, 298-313, 2011.

McAnena, A., Flögel, S., Hofmann, P., Herrle, J. O., Griesand, A., Pross, J., Talbot, H. M., Rethemeyer, J., Wallmann, K., and Wagner, T.: Atlantic cooling associated with a marine biotic crisis during the mid-Cretaceous period, Nat. Geosci., 6, 558-561, https://doi.org/10.1038/NGEO1850, 2013.

Miller, K. G., Mountain, G. S., Wright, J. D., and Browning, J. V.: A 180-million-year record of sea level and ice volume variations from continental margin and deep-sea isotopic records, Oceanography, 24, 40-53, https://doi.org/10.5670/oceanog.2011.26, 2011.
Mutterlose, J. and Kessels, K.: Early Cretaceous calcareous nannofossils from high latitudes: implications for palaeobiogeography and palaeoclimate, Palaeogeogr. Palaeocl., 160, 347-372, 2000.

Mutterlose, J., Bornemann, A., and Herrle, J. O.: The AptianAlbian cold snap: Evidence for "mid" Cretaceous icehouse interludes, Neues Jahrb. Geol. P.-A., 232, 217-225, 2009.

Ogg, J. G. and Hinnov, L. A.: Cretaceous, in: The Geologic Time Scale 2012 - Volume 2, edited by: Gradstein, F. M., Ogg, J. G., Schmitz, M. D., and Ogg, G. M., Elsevier, 793-855, 2012.

Owen, H. G.: Middle Albian stratigraphy in the Anglo-Paris Basin, Bulletin of the British Museum (Natural History) Geology, Supplement 8, 164 pp., 1971.

Owen, H. G.: Ammonite faunal provinces in the Middle and Upper Albian and their palaeogeographical significance, in: The Boreal Lower Cretaceous: Proceedings of an International Symposium organized by Queen Mary College (University of London) and the Institute of Geological Sciences, edited by: Casey, R. and Rawson, P. F., 17-30 September 1972, 145-154, 1973.

Owen, H. G.: The stratigraphy of the Gault and the Upper Greensand of the Weald, P. Geologist. Assoc., 86, 475-498, 1975.

Pirrie, D., Marshall, J. D., Doyle, P., and Riccardi, A. C.: Cool early Albian climates: new data from Argentina, Cretaceous Res., 25, 27-33, 2004.

Roth, P. H. and Bowdler, J. K.: Middle Cretaceous calcareous nannoplankton biogeography and oceanography of the Atlantic Ocean, SEPM Spec. P., 32, 517-546, 1981.

Roth, P. H. and Krumbach, K. R.: Middle Cretaceous calcareous nannofossil biogeography and preservation in the Atlantic and Indian oceans: Implications for paleoceanography, Mar. Micropaleontol., 10, 235-266, 1986.

Shackleton, N. J. and Kennett, J. P.: Paleotemperature history of the Cenozoic and the initiation of Antarctic glaciation: oxygen and carbon isotope analysis in DSDP Sites 277, 279, and 280, in: Initial Reports of the DSDP, edited by: Kennett, J. P., Houtz, R. E., Andrews, P. B., Edwards, A. R., Gostin, V. A., Hajós, M., Hampton, M. A., Graham Jenkins, D., Margolis, S. V., Ovenshine, A. T., and Perch-Nielsen, K., Vol. 29: Washington D. C., US Govt. Printing Office, 743-755, https://doi.org/10.2973/dsdp.proc.29.117.1975, 1975.

Street, C. and Bown, P. R.: Palaeobiogeography of Early Cretaceous (Berriasian-Barremian) calcareous nannoplankton, Mar. Micropaleontol., 39, 265-291, 2000.

Thomsen, E.: Seasonal variation in Boreal Early Cretaceous calcareous nannofossils, Mar. Micropaleontol., 15, 123-152, 1989.

Tyson, R. V. and Funnel, B. M.: European Cretaceous shorelines, stage by stage, Palaeogeogr. Palaeocl., 59, 69-91, 1987.

Ufnar, D. F., González, L. A., Ludvigson, G. A., Brenner, R. L., and Witzke, B. J.: The mid-Cretaceous water bearer: isotope mass balance quantification of the Albian hydrologic cycle, Palaeogeogr. Palaeocl., 188, 51-71, 2002.

Wagner, T., Wallmann, K., Herrle, J. O., Hofmann, P., and Stuesser, I.: Consequences of moderate $\sim 25,000 \mathrm{yr}$ lasting emission of light $\mathrm{CO}_{2}$ into the mid-Cretaceous ocean, Earth Planet. Sc. Lett., 259, 200-211, 2007.

Wagner, T., Herrle, J. O., Sinnighe Damsté, J. S., Schouten, S., Stuesser, I., and Hofmann, P.: Rapid warming and salinity changes of Cretaceous surface waters in the subtropical North Atlantic, Geol. Soc. Am., 36, 203-206, https://doi.org/10.1130/G24523A.1, 2008. 
Watkins, D. K., Cooper, M. J., and Wilson, P. A.: Calcareous nannoplankton response to late Albian oceanic anoxic event 1d in the western North Atlantic, Paleoceanography, 20, PA2010, https://doi.org/10.1029/2004PA001097, 2005.

Wilson, P. A., Norris, R. D., and Cooper, M. J.: Testing the Cretaceous greenhouse hypothesis using glassy foraminiferal calcite from the core of the Turonian tropics on Demerara Rise, Geol. Soc. Am., 30, 607-610, 2002.

Wise, S. W.: Mesozoic and Cenozoic calcareous nannofossils recovered by DSDP Leg 71 in the Falkland Plateau region, Southwest Atlantic Ocean, Initial Reports of the DSDP, 71, 481-550, 1983.

Wise, S. W.: Mesozoic-Cenozoic history of calcareous nannofossils in the region of the Southern Ocean, Palaeogeogr. Palaeocl., 67, 157-179, 1988.
Young, J. R.: Calcareous nannofossils, in: Palaeontological Association Field Guide to Fossils, edited by: Young, J. R., Gale, A S., Knight, R. I., and Smith, A. B., Palaeontological Association, UK, 12, 16-27, 2010.

Young, J. R., Gale, A. S., Knight, R. I., and Smith, A. B. (Eds.): Palaeontological Association Field Guide to Fossils, 12, 312 pp., Palaeontological Association, UK, 2010. 